\title{
富山県北西部の鮮新-更新統，藪田層と十二町層の火山灰層による対比と 十二町層下部の珪藻・石灰質ナンノ化石層序
}

Stratigraphic correlation between the Plio-Pleistocene Yabuta and Junicho Formations using volcanic ash beds, and diatom and calcareous nannofossil biostratigrahy of lower part of the Junicho Formation in northwestern Toyama Prefecture, Central Japan

\section{大久保 弘* 佐藤時幸** 渡辺真人***}

\section{Hiroshi Ohkubo*, Tokiyuki Sato** and Mahito Watanabe ${ }^{* * *}$}

1999 年 11 月 12 日受付.

2000 年 4 月 24 日受理

* 金沢大学理学部地球学科

Department of Earth Sciences, Faculty of

Science, Kanazawa University, Kakuma,

Kanazawa 920-1192, Japan

** 秋田大学工学資源学部地球資源学科

Department of Earth Science and Technology, Faculty of Engineering and Resource Science, Akita University, Tegatagakuen 1-1, Akita 010-8502, Japan

*** 地質調查所資源エネルギー地質部

Mineral and Fuel Resources Department Geological Survey of Japan, Tsukuba 3058567, Japan

\begin{abstract}
The Yabuta Formation consists of the early to late Pliocene marine sediments distributed along the Nadaura coast, and the Junicho Formation includes late Pliocene to early Pleistocene marine sediments near Asahiyama hill, in northwestern part of Toyama Prefecture.

We examined volcanic ash beds in the Yabuta and Junicho Formations by petrographical method and measuring chemical component of volcanic glass. Two pairs of the volcanic ash beds (MT2-T1, UN-T3) can be correlated between the Yabuta and Junicho Formations, and the middle-upper part of the Yabuta Formation can be correlated to the lower part of the Junicho Formation. Fossil diatoms from the lower part of the Junicho Formation showed that the boundary between the Neodenticula koizumii-Neodenticula kamtschatica Zone and the N. koizumii Zone is around the T3 volcanic ash bed that is widely traced in the Hokuriku Region. Calcareous nannofossil biostratigraphy of the lower part of the Junicho Formation indicates that Datum A (2.75 Ma) is demarcated about 4 meter below the T3 volcanic ash bed. A widespread tephra of the Habutaki I-MT2 ash layer is situated about $14 \mathrm{~m}$ below the Datum $A$ in the Junicho Formation.
\end{abstract}

Key words : Plio-Pleistocene, Yabuta Formation, Junicho Formation, volcanic ash bed, diatom, calcareous nannoplankton
はじめに

能登半島南東部の水見市西方から灘浦海岸地域にかけての 一帯には，新第三系が広く分布している（Fig. 1). 特に灘浦 海岸沿いは露出状態が良好で，北陸堆積盆の模式層序として 微化石層序の検討が多く行われてきた（中世古ほか，1972な ご). 藪田層と十二町層はこれら新第三系の最上位に位置し, それぞれ藪田-灘浦海岸地域と朝日山周辺に分布している. 藪田層は分布域全般に珪藻化石層序の検討がなされ，鮮新世 前期から後期であるこよが示されている（渡辺，1990）. 方, 十二町層は石灰質ナンノ化石層序により鮮新世後期から 更新世前期とされている（高山ほか，1988）。

一方，両層の古環境に関する研究として，藪田層上部から は介形虫群集の $40 \mathrm{ka}-45 \mathrm{ka}$ の周期的変化と $2.4 \mathrm{Ma}$ 付近の 寒冷性介形虫のスパイク的な比率の増加の存在が報告され (Cronin et al., 1994)，また十二町層中部では約 4 万年周期の 磁性鉱物量の変動（Arai et al., 1997）と浮遊性有孔虫化石群 集の変化（荒井ほか，1998）が報告されており，古海洋の周 期的な変動に起因すると考えられている.

このように藪田・十二町画層では古海洋変動に起因する微
化石群集等の変動が検討されているが，両層間の対比に関し ては，産状の似た火山灰層を対比して示した例（Hasegawa， 1979）や，浮遊性有孔虫化石層序により藪田層亡十二町層の 対比を試みた例（両角・石垣，1981）がある。しかし前者に 関しては対比の根拠にそしく，後者に関しても時間的精度が 十分であるとはいいがたい状況にある。むし藪田・十二町層 間で厳密な対比が実現すれば，両層で報告された古海洋変動 の記録の層序学的位置関係が明確になり, 古海洋变動の記録 を連続的にすることあ可能となると考えられる.

本研究は数厅年オーダーの古海洋变動の記録が報告されて いる藪田・十二町両層の厳密な対比を目的として，火山灰層 の検討を行った。また本研究で得られた火山灰層の対比を検 証するため, 亚びに大久保（1999）により北陸地域に広く追 跡された T3 火山灰層の年代を求めるために，十二町層下部 において珪藻化石・石灰質ナンノ化石層序の詳細な検討を 行った。 その結果, 藪田・十二町層間の対比を確立し, 新た な知見を得たので報告する. 


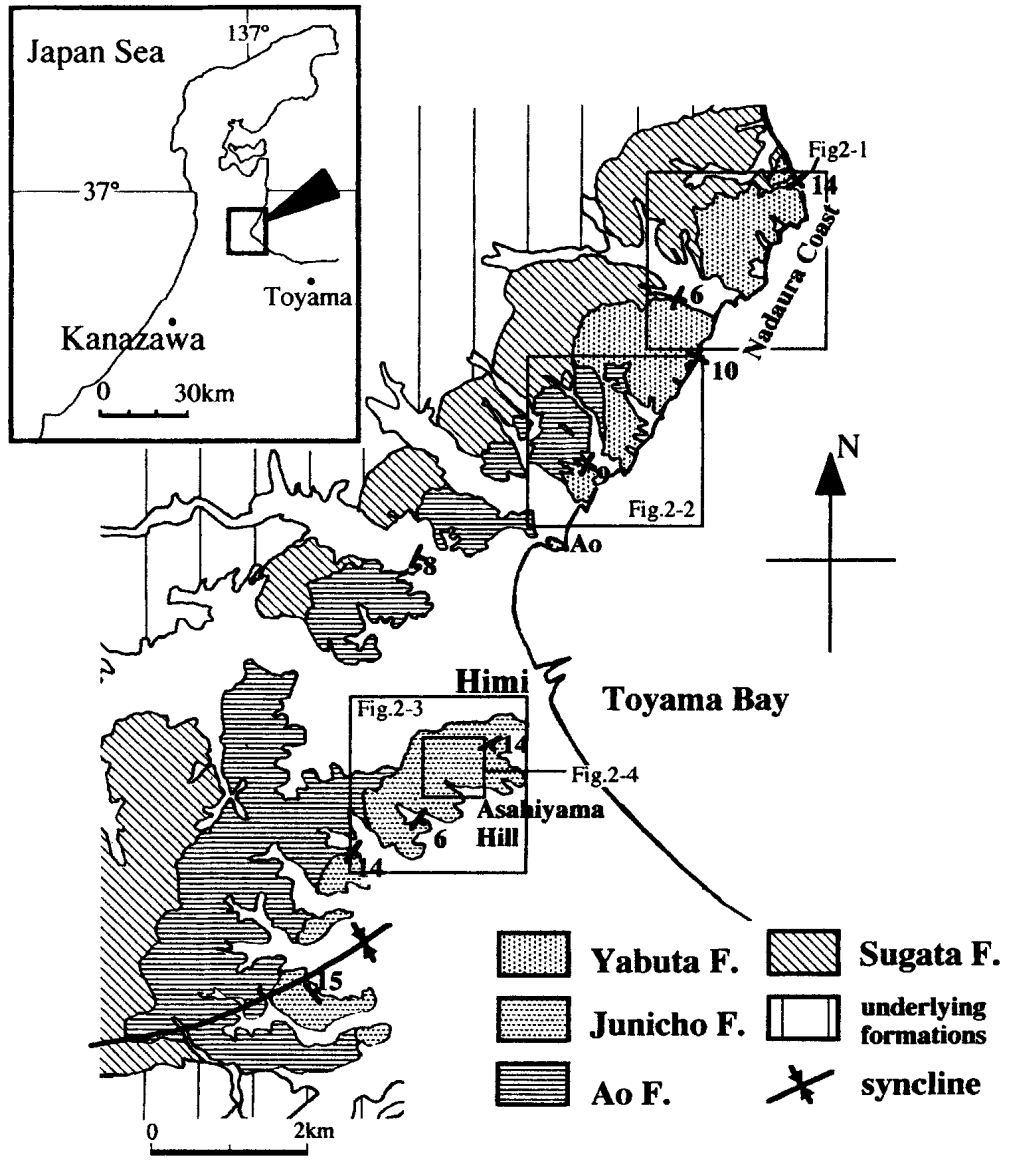

Fig. 1. Geological Map of the Nadaura-Asahiyama area (modified from Hasegawa, 1979 and Watanabe, 1990).

\section{地 質 概 要}

\section{1. 灘浦海岸-阿尾地域}

灘浦海岸-阿尾地域には, 中部・上部中新統〜上部鮮新統 が広く分布し, 下位より姿層 (中部・上部中新統; 渡辺, 1990), 阿尾層 (上部中新統〜下部鮮新統; 渡辺, 1990), 藪田 層と区分されている(池辺, 1949). 本研究の対象である數田 層は層厚 $120 \mathrm{~m}$ 以上（渡辺, 1990）で, 岩相は石灰質砂質シ ルト岩からなり, 石灰質コンクリーションを層状またはレン ズ状に挟んでいる。一方, 下位の阿尾層は塊状の泥岩から構 成されている. 阿尾層は宇波 (Fig. 2-1) 以南では數田層之整 合関係で接しているが, 小境・大境付近 (Fig. 2-1) では消滅 し, 姿層と數田層が層厚 $1 \mathrm{~m}$ 前後の大境海緑石砂岩層を挟ん で接している（渡辺，1990）。渡辺（1990）は珪澡化石層序を 用いて姿層之阿尾・藪田層の問に時間問隙を認め, 大境海緑 石砂岩層が無堆積状態下で形成されたもの之推定している.

\section{2. 朝日山地域}

この地域は朝日山周辺を中心之し, 鮮新統から更新統が分 布している.これらの地層は下位上り阿尾層, 十二町層, 埴 生層と区分されている (長谷川・小林, 1986). 十二町層は層 厚約 $120 \mathrm{~m}$ で, 上部に厚さ $10 \mathrm{~m}$ ほどの石灰質粗粒砂岩層が 2 枚挟まれる以外は石灰質細粒砂岩を主体としている。また， 數田層之同様に十二町層の中部層準には石灰質コンクリー ションを層状またはレンズ状に挟んでいる，阿尾層の岩相は 灘浦地域之同じく塊状の泥岩である。阿尾層と十二町層は不
整合関係にあり, 本研究の調査対象である清水一矢崎ルート に近接する荒館集落北方の林道沿いにおいて T1 火山灰層の 直下に両層の不整合境界が報告されている (Arai et al., 1991).

\section{火山灰層の検討}

\section{1. 試料採取地点}

本研究では灘浦海岸-阿尾地域之朝日山地域において藪田 層と十二町層の主要な 15 の火山灰層を検討対象とした。 火 山灰層試料は灘浦海岸-阿尾地域の藪田層については渡辺 （1990）の記載をむとに採取を行った. 朝日山地域の十二町層 では T3 火山灰層 (Arai et al., 1991) 以外は大久保 (1999) と同一のあのを使用し，新たに試料採取を行わなかった。な 押, 灘浦海岸-阿尾地域の火山灰層試料の採取地を Fig. 2-1 と 2-2 に, 朝日山地域について Fig. 2-3 と 2-4 に示す.

灘浦海岸-阿尾地域：YT3 (阿尾森林公園; Fig. 2-2), YT4 (阿尾森林公園; Fig. 2-2), TT1 (小杉; Fig. 2-2), TT2 (泊; Fig. 2-2), MT2 (水見グランドホテルマイアミ前; Fig. 2-1), UN (小境; Fig. 2-1), OT5 (大境; Fig. 2-1).

朝日山地域: T1（清水-矢崎; Fig. 2-4), T2（荒館; Fig. 23), T3（清水-矢崎; Fig. 2-4), T4（坂津 ; Fig. 2-3）, T6 (清水-矢崎; Fig. 2-4), T8（荒館; Fig. 2-3）, T9（朝日丘; Fig. 2-3).

\section{2. 分析方法}

本研究では野外で産状, 層序学的位置を検討し, 光学顕微 

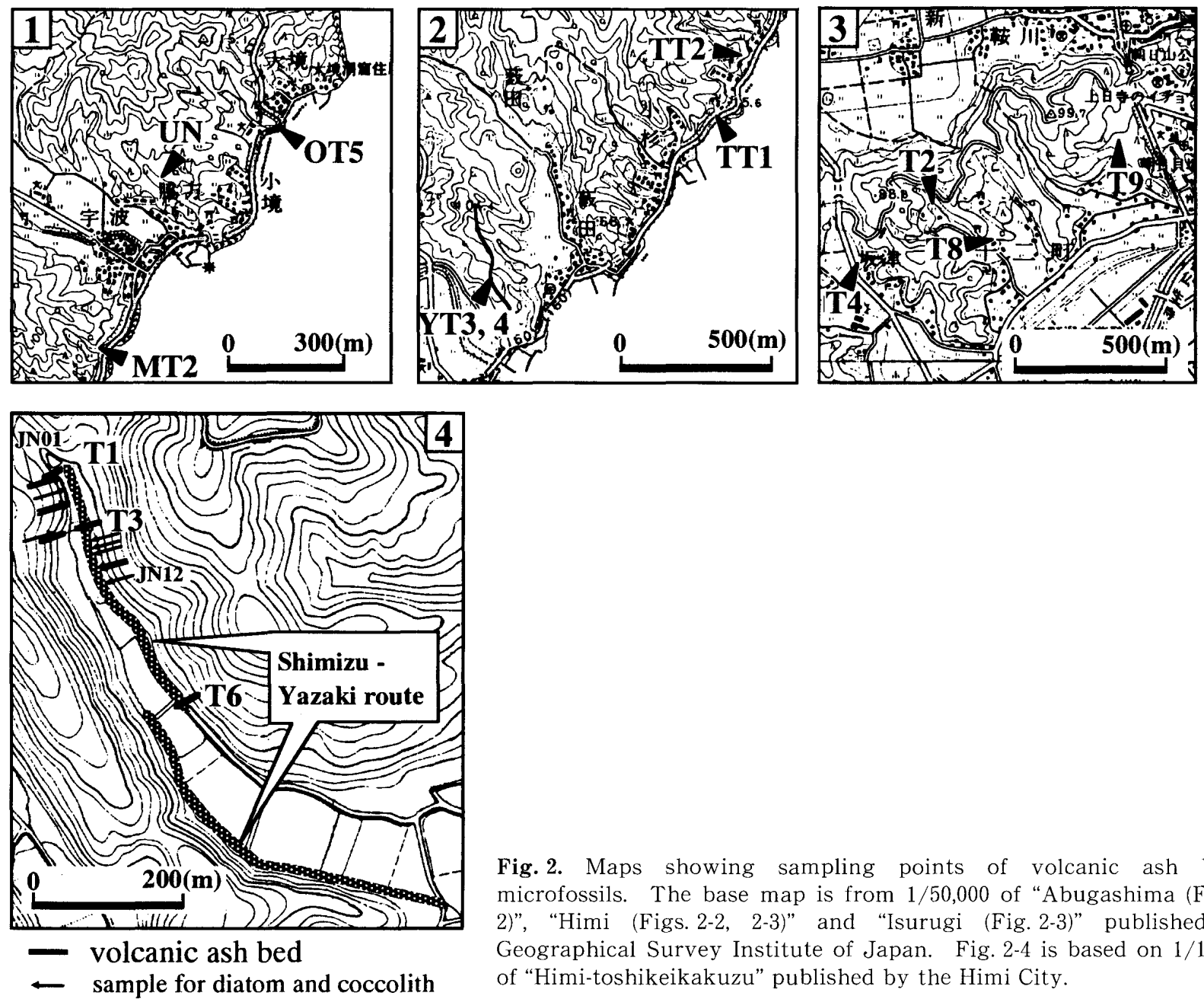

Fig. 2. Maps showing sampling points of volcanic ash beds and microfossils. The base map is from 1/50,000 of "Abugashima (Figs. 2-1, 22)", "Himi (Figs. 2-2, 2-3)" and "Isurugi (Fig. 2-3)" published by the Geographical Survey Institute of Japan. Fig. 2-4 is based on 1/10,000 map of "Himi-toshikeikakuzu" published by the Himi City.

鏡下で全鉱物組成・火山ガラスの形状割合・重鉱物組み合わ せの検討を行った。 さらに EDS (energy dispersive X-ray spectrometry）を用いた火山ガラスの主成分組成の検討を 行い, 火山灰層の対比を試みた。

試料処理は原試料を破砕, 洗浄, 乾燥させた後, 目開き 500 $\mu \mathrm{m} \sim 63 \mu \mathrm{m}$ のふるいを 2 分の $1 \phi$ スケールごとに用いてふる い分けを行った．光学顕微鏡下での検討用と EDSの分析用 の試料は粒径 180-125 $\mu \mathrm{m}$ に統一し，1 g の火山死試料を Palouse Petro Products 社の Petropoxy 154 を用いてスラ イドガラス上に封入した.

全鉱物組成と火山ガラスの形状割合は，顕微鏡下で 200 個 以上カゥントして百分率で示した (Table 1). 火山ガラスの 形状分類は吉川（1976）の分類に従った。重鉱物の記載につ いては，本研究で扱った火山灰試料は重鉱物が極端に少ない ガラス質のものが多く，重鉱物のカウント数は 200 個に満た ないので定性的に示し，参考程度によどめた。また，重鉱物 が極端に少ない試料は必要に応じて追加を行った。

EDSによる測定試料は，火山灰粒子の断面が出るように 400 \# 6000\#の研磨剤で研磨した後, ダイヤモンドペース トで研磨した，化学組成の測定は金沢大学の明石製作所製工 ネルギー分散型 EPMA $\alpha$-30A SEM-EDAX9100によって測 定した. $\mathrm{Fe}$ は $\mathrm{FeO}$ と $\mathrm{Fe}_{2} \mathrm{O}_{3}$ の合計を $\mathrm{FeO}^{*}$ として示した.
測定は走査型顕微鏡下で 1000 倍前後の倍率で 1 試料につき 火山ガラス 10 個体以上行い, 分析結果を比較するため測定 結果を $100 \%$ に再計算し，標準偏差を求めた（Table 2).

\section{3. 火山灰層の産状亡記載的特徵}

検討した 15 枚の火山扊層のうち，大久保 (1999) で記載さ れた T2，T6，T8 火山灰層を除いた 12 枚の火山灰層につい て産状と特徴を以下に示す，検討したすべての火山灰層につ いて，それらの層序関係を Fig. 3 に，分析結果を Tables 1 , 2 に示す.

\section{（1） 灘浦海岸-阿尾地域}

YT3 火山灰層（渡辺，1990）

水見市藪田の川沿いの露頭を模式地とし, 藪田層の基底に 挟在する（渡辺，1990）。本研究では渡辺（1990）により報告 された阿尾森林公園のYT3 火山灰層を検討した，森林公園 では層厚 $45 \mathrm{~cm}$ で, 白色のガラス質火山灰層である. 下部 10 $\mathrm{cm}$ が中粒砂サイズから極細粒砂サイズへと級化し, それよ り上位はシルトサイズの火山灰である。火山ガラスの形状は 突起を持っ扁平型 $(\mathrm{Hb})$ が半数前後を占めている（Table 1). 重鉱物は黒雲母, 斜方輝石, 不透明鉱物, 角閃石, 単斜 輝石を含む. 火山ガラスの化学組成は $\mathrm{SiO}_{2}$ の值が $77.06 \%$ 前 後とやや高めで, $\mathrm{CaO}$ の值が $0.44 \%$ 前後と低い（Table 2 ; Fig. 6). 

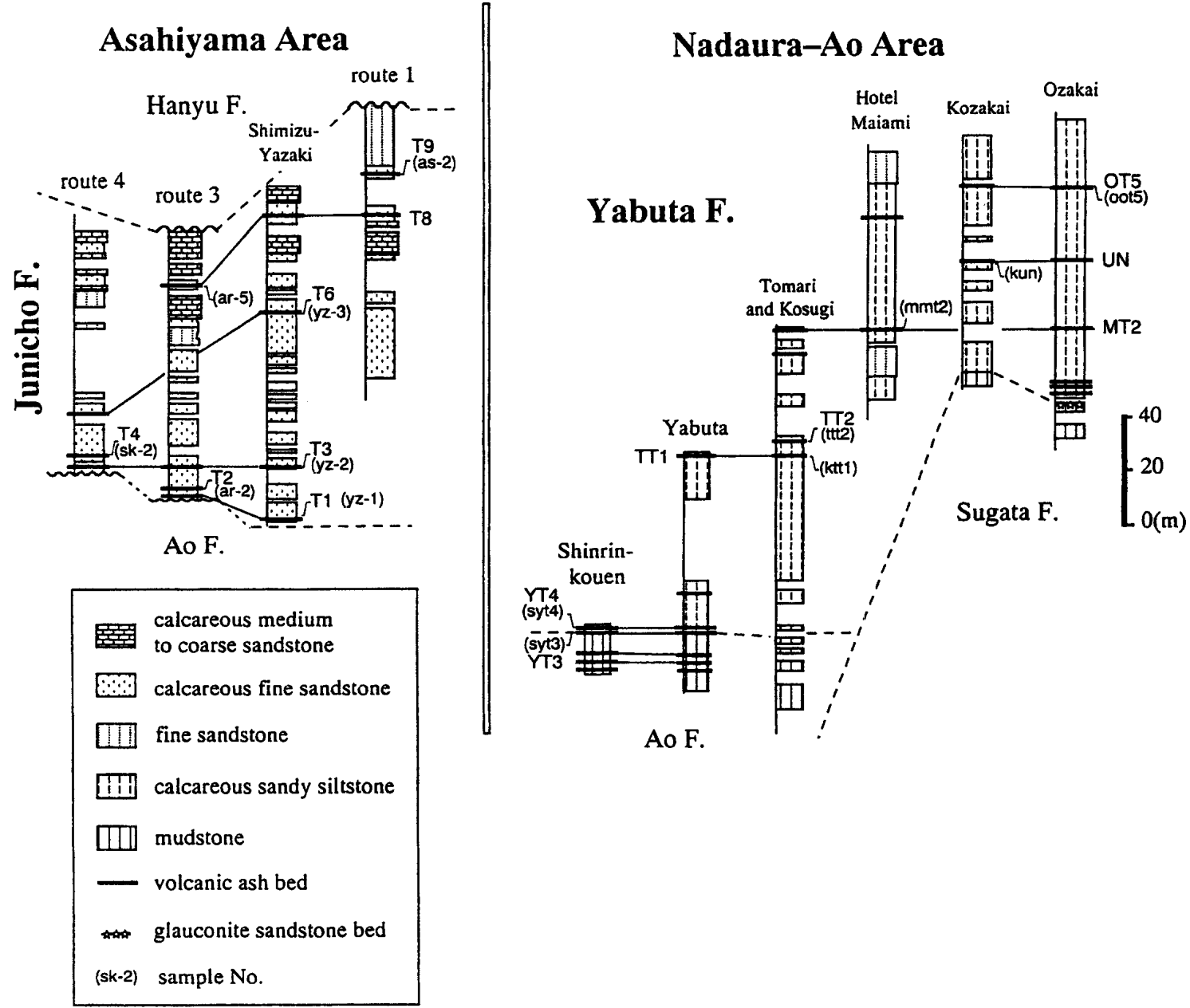

Fig. 3. Columnar sections of the Junicho and Yabuta Formations, and stratigraphic horizons of volcanic ash beds. In the Asahiyama area, the route 1, 3 and 4 are modified from Arai et al. (1991). In the Nadaura-Ao area, each section is modified from Watanabe (1990).

\section{YT4 火山灰層（渡辺，1990）}

水見市藪田の川沿いの露頭を模式地とし, YT3 火山兏層 の約 $2.5 \mathrm{~m}$ 上位に位置する（渡辺，1990）。本研究では YT3 と同様に阿尾森林公園の YT4 火山灰層を検討した。 森林公 園では層厚 $20 \mathrm{~cm}$ で，灰白色のガラス質火山灰層である。下 部 $10 \mathrm{~cm}$ が細粒砂・極細粒砂サイズでシルトサイズへと級 化し，上部 $10 \mathrm{~cm}$ はシルトサイズである. 火山ガラスの形状 は中間型 ( $\mathrm{Ca}, \mathrm{Cb})$ が多い（Table 1)。重鉱物は黒雲母，不 透明鉱物を含む. 火山ガラスの化学組成は $\mathrm{SiO}_{2}$ と $\mathrm{CaO}$ の值 がそれぞれ $75.13 \%$ 前後, $0.67 \%$ 前後と比較的低めで $\mathrm{Al}_{2} \mathrm{O}_{3}$ の值が $13.87 \%$ 前後と比較的高い值を示す（Table 2 ; Fig. 6).

TT1 火山灰層（渡辺，1990）

水見市泊の国道 160 号沿いの露頭を模式地とし, 藪田層下 部の石灰質シルト岩層中に挟在する（渡辺，1990）。模式地に おける層厚は約 $75 \mathrm{~cm}$. 下部 $15 \sim 17 \mathrm{~cm}$ 付近までは数 $\mathrm{mm}$ 大 の軽石や岩片を含む褐色中粒砂サイズの結晶質ガラス質火山 灰，それより上位は灰白色のガラス質火山灰で細粒砂サイズ からシルトサイズへと級化を示す。火山ガラスの形状は中間 型（Ca）が多い（Table 1)。重鉱物は斜方輝石，黒雲母，不 透明鉱物を含む. 火山ガラスの化学組成は $\mathrm{SiO}_{2}$ の值が
$75.11 \%$ 前後と比較的低めで, $\mathrm{Al}_{2} \mathrm{O}_{3}$ の值が $13.7 \%$ 前後と比 較的高い值を示す（Table 2 ; Fig. 6).

TT2 火山灰層（渡辺，1990）

水見市泊の国道 160 号沿いの露頭を模式地とし, TT 1 の $4.5 \mathrm{~m}$ 上位に位置する（渡辺，1990）。模式地では層厚約 25 $\mathrm{cm}$ で，灰色のガラス質火山灰層である。部約 $5 \mathrm{~cm}$ が極細 粒砂サイズ，それより上位がシルト質のシルトサイズへと変 化する. 火山ガラスの形状は中間型 (Ca) が多い（Table 1). 重鉱物は斜方輝石, 黒雲母, 角閃石を含む. 火山ガラスの化 学組成は $\mathrm{SiO}_{2}$ の值が $73.77 \%$ 前後と低く, $\mathrm{FeO}^{*}$ と $\mathrm{CaO}$ の值 がそれぞれ $2.79 \% ， 2.88 \%$ 前後と高い值を示す（Table 2; Fig. 6).

\section{MT2 火山灰層（渡辺，1990）}

水見市泊のホテルマイアミの前を模式地とし，藪田層中部 の石灰質シルト岩層中に挟在する，大境では基底の大境海緑 石砂岩層加ら約 $35 \mathrm{~m}$ 程度上位に位置する（渡辺，1990）。模 式地では層厚約 $90 \mathrm{~cm}$ のガラス質火山灰層で，基底から 2 $\mathrm{cm}$ までは死白色を示すが，それより上位は風化の影響と考 えられる黄褐色を示す，基底から $20 \mathrm{~cm}$ までは極細粒砂サイ ズからシルトサイズへと級化し， $20 \mathrm{~cm}$ 付近から極細粒砂サ イズに変化して再びシルトサイズへと級化する (Fig. 4). 火 


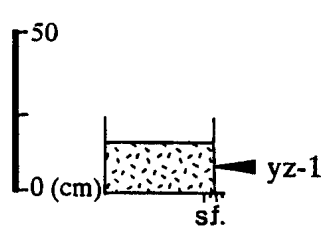

T1 Volcanic

Ash Bed

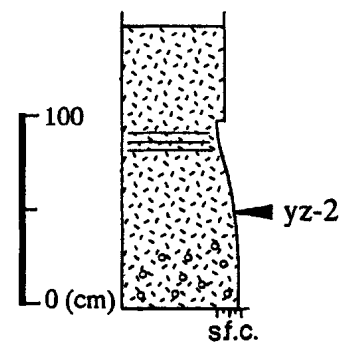

T3 Volcanic

Ash Bed

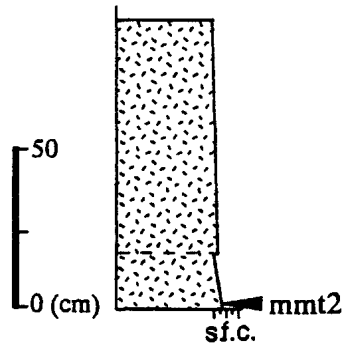

MT2 Volcanic

Ash Bed

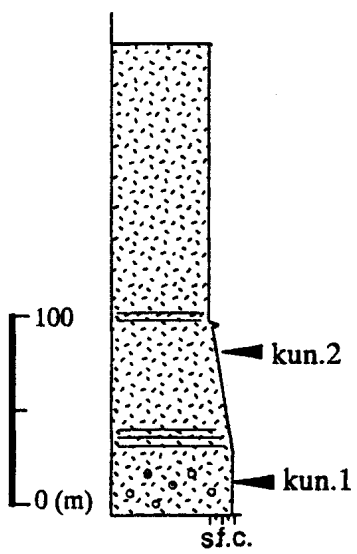

UN Volcanic

Ash Bed

$\begin{array}{llll}\text { lat.c. } & \text { grain size } \\ \text { lamination } & \text { f. } & \text { fine sand size ash } \\ \text { akun.1 } & \begin{array}{l}\text { Sample, and } \\ \text { sampling number }\end{array} & \text { c. } & \text { coarse sand size ash } \\ \end{array}$

Fig. 4. Columnar sections of the selected volcanic ash beds.

山ガラスの形状は薄手の突起を持つ扁平型 $(\mathrm{Hb})$ が多い (Table 1 ; Fig. 5). 構成粒子は火山ガラスが大半を占め, 石 英や長石等の軽鉱物を少量含み, 重鉱物は斜方輝石, 角閃石, 単斜輝石, 不透明鉱物を含む. 火山ガラスの化学組成は $\mathrm{SiO}_{2}$ の值が $78.64 \%$ 前後と比較的高く, $\mathrm{Al}_{2} \mathrm{O}_{3}$ の值が $12.02 \%$ 前後 と比較的低い值を示す (Table $2 ;$ Fig. 6).

UN 火山灰層（渡辺，1990）

水見市宇波集落南側の用水路沿いを模式地とし, 藪田層上 部の石灰質シルト岩層中に挟在する（渡辺, 1990). 水見市大 境では MT 2 の約 $25 \mathrm{~m}$ 上位に位置している. 本研究では水 見市小境西方の沢で試料を採取した，小境では層厚約 $2.5 \mathrm{~m}$ のガラス質火山灰層で，その上限は露頭の欠落により定かで はない. 本火山灰層は基底〜 $30 \mathrm{~cm}$ までは径数 $\mathrm{mm}$ 大の軽石 を含む中粒砂サイズであるが，30-60 cm 付近で葉理を伴い ながら $1 \mathrm{~m}$ の層準まで極細粒砂サイズへと級化し， $1 \mathrm{~m}$ の層 準付近で葉理を伴った細粒砂サイズへと粗粒化したのちシル トサイズへと細粒化している(Fig. 4). 火山ガラスの形状は 厚手の直線状の突起を持つ扁平型 ( $\mathrm{Hb}$ 型) や直線状の気泡 を持つ中間型 ( $\mathrm{Cb}$ 型) が多い（Table $1 ;$ Fig. 5). 構成粒子 は約 $97 \%$ が火山ガラスで, 石英, 長石等の軽鉱物を少量含 み，重鉱物はわずかに黒雲母と不透明鉱物を含む. 火山ガラ スの化学組成は $\mathrm{SiO}_{2}$ の值が 77.37-77.46\% 前後と比較的高め で, $\mathrm{CaO}$ の值が 0.61-0.66\% 前後と低めである（Table 2; Fig. 6).

OT5 火山灰層（渡辺，1990）

大境の国道 160 号線沿いの露頭を模式地とし（渡辺, 1990), 藪田層上部の石灰質シルト岩層中に挟在する. 模式地 では層厚 $70 \mathrm{~cm}$, 黄褐色を帯びた死白色ガラス質火山灰層で
ある. 下部は極細粒砂サイズが主体だが，シルトサイズ主体 へと弱い級化を示す. 火山ガラスの形状割合は突起を持つ扁 平型 (Hb) が多くを占める (Table 1). 重鉱物は黒雲母を比 較的多く含み, 不透明鉱物, 斜方輝石を含んでいる. 火山ガ ラスの化学組成は $\mathrm{SiO}_{2}$ の值が $75.86 \%$ 前後と比較的低めで, $\mathrm{CaO}$ の值が $1.13 \%$ 前後と比較的高めである（Table 2 ; Fig. $6)$.

（2）朝日山地域

T1 火山灰層 (Arai et al., 1991)

この火山灰層は清水集落北西の貯水池西側の露頭 (Fig. 24）を模式地とし（大久保, 1999), 十二町層最下部付近の石 灰質細粒砂岩層中に挟在する，西側に隣接する荒館北方の林 道沿いでは下位の阿尾層との不整合境界の直上に挟まれてい る (Arai et al., 1991). 模式地での層厚は約 $20 \mathrm{~cm}$ であるが, 上限は生物擾乱により乱されており, 不明瞭である. 色は灰 白色を示し，粒度は細粒〜極細粒砂サイズである．火山ガラ スの形状は薄手の突起を持つ扁平型 (Hb) が多い（Table 1; Fig. 5). 構成粒子は火山ガラスが大半を占め, 石英や長石等 の軽鉱物を少量含み, 重鉱物は斜方輝石, 角閃石, 不透明鉱 物, 単斜輝石を含む. 火山ガラスの化学組成は $\mathrm{SiO}_{2}$ の值が $78.47 \%$ 前後と高く, $\mathrm{Al}_{2} \mathrm{O}_{3}$ の值が $11.88 \%$ 前後と比較的低い (Table 2 ; Fig. 6 ).

T3 火山灰層 (Arai et al., 1991)

この火山灰層は氷見市坂津の民家裏の露頭を模式地とし (大久保, 1999), 十二町層下部に挟在する. 本研究では清水 北西の露頭 (Fig. 2-4) の T3 火山灰層を検討した. 本火山灰 層は軽石を含む白色のガラス質火山灭層で, 清水一矢崎ルー トでは T1の約 $17 \mathrm{~m}$ 上位に位置し, 層厚約 $1.5 \mathrm{~m}$ である.多 
Table 1. Lithofacies and petrographic properties of volcanic ash beds in the Nadaura-Ao area (1-a) and the Asahiyama area (1-b). Classification of volcanic glass shapes ( $\mathrm{Ha}, \mathrm{Hb}, \mathrm{Ca}, \mathrm{Cb}, \mathrm{Ta}$ and $\mathrm{Tb}$ ) is based on Yoshikawa (1976).

Table 1-a, Nadaura-Ao Area

\begin{tabular}{|c|c|c|c|c|c|c|c|c|c|c|c|c|c|c|c|}
\hline \multirow[b]{2}{*}{ Name } & \multirow[b]{2}{*}{$\mathrm{F}}$. & \multirow[b]{2}{*}{ Sample No. } & \multirow{2}{*}{$\begin{array}{l}\text { Grain } \\
\text { Size } \\
\end{array}$} & \multirow[b]{2}{*}{ Color } & \multirow[b]{2}{*}{ Thickness } & \multicolumn{3}{|c|}{ Mineral composition } & \multicolumn{6}{|c|}{ Glass shape } & \multirow{2}{*}{$\begin{array}{l}\text { Heavy } \\
\text { minerals }\end{array}$} \\
\hline & & & & & & G. & L.M. & H.M. & $\mathrm{Ha}$ & $\mathrm{Hb}$ & $\mathrm{Ca}$ & $\mathrm{Cb}$ & $\mathrm{Ta}$ & $\mathrm{Tb}$ & \\
\hline OT5 & $\mathrm{Ya}$ & oot5 & v.f.-s. & y.w. & $70 \mathrm{~cm}$ & 98 & 2 & * & 1 & 46 & 14 & 24 & 6 & 9 & Bt, Opq, Opx \\
\hline UN & $\mathrm{Ya}$ & kun.1 & m.-s. & w. & $250 \mathrm{~cm}$ & 97 & 3 & * & 1 & 55 & 33 & 10 & $\star$ & 1 & $\mathrm{Bt}, \mathrm{Opq}$ \\
\hline MT2 & $\mathrm{Ya}$ & $\mathrm{mmt2}$ & v.f.-s. & w. & $90 \mathrm{~cm}$ & 100 & $\star$ & 0 & 8 & 60 & 16 & 13 & 3 & 2 & Opx, Cpx, Am, Opq \\
\hline$\pi 2$ & $\mathrm{Ya}$ & ttt2 & v.f.-s. & g. & $20 \mathrm{~cm}$ & 88 & 11 & * & 0 & 12 & 27 & 46 & 9 & 7 & Opx, Bt, Am \\
\hline$\pi 1$ & $\mathrm{Ya}$ & ktt1 & m.-s. & w. & $75 \mathrm{~cm}$ & 92 & 8 & * & $\star$ & 14 & 15 & 51 & 6 & 14 & Opx, Bt, Opq \\
\hline $\mathrm{YT4}$ & $\mathrm{Ya}$ & syt4 & f.-s. & g.w. & $20 \mathrm{~cm}$ & 94 & 5 & 1 & 0 & 16 & 30 & 40 & 7 & 7 & $\mathrm{Bt}, \mathrm{Opq}$ \\
\hline YT3 & $\mathrm{Ya}$ & syt3 & m.-s. & w. & $45 \mathrm{~cm}$ & 95 & 4 & 1 & 9 & 51 & 28 & 9 & 2 & 2 & $B t, O p x$, Opq, Am, Cpx, \\
\hline
\end{tabular}

Table 1-b, Asahiyama Area

\begin{tabular}{|c|c|c|c|c|c|c|c|c|c|c|c|c|c|c|c|}
\hline \multirow[b]{2}{*}{ Name } & \multirow[b]{2}{*}{$\mathrm{F}}$. & \multirow[b]{2}{*}{ Sample No. } & \multirow{2}{*}{$\begin{array}{l}\text { Grain } \\
\text { Size }\end{array}$} & \multirow[b]{2}{*}{ Color } & \multirow[b]{2}{*}{ Thickness } & \multicolumn{3}{|c|}{ Mineral composition } & \multicolumn{6}{|c|}{ Glass shape } & \multirow{2}{*}{$\begin{array}{l}\text { Heavy } \\
\text { minerals }\end{array}$} \\
\hline & & & & & & G. & L.M. & H.M. & $\mathrm{Ha}$ & $\mathrm{Hb}$ & $\mathrm{Ca}$ & $\mathrm{Cb}$ & $\mathrm{Ta}$ & Tb & \\
\hline T9 & Ju & as-2 & f.-s. & g.w & $20 \mathrm{~cm}$ & 99 & 1 & 0 & 1.9 & 35 & 30 & 20 & 2.4 & 11 & $\mathrm{Bt}, \mathrm{Am}$ \\
\hline T8 & $\mathrm{Ju}$ & ar-5 & f.-s. & w. & $10 \mathrm{~cm}$ & 65 & 4 & 31 & 7.2 & 28 & 27 & 31 & * & 5.1 & $B t, O p q, A m$ \\
\hline T6 & $\mathrm{Ju}$ & $y z-3$ & f.-s. & w.g. & $15 \mathrm{~cm}$ & 99 & 1 & * & 4 & 9.5 & 41 & 17 & 16 & 11 & Opx, Am, Opq, Cpx, Bt \\
\hline T4 & $\mathrm{Ju}$ & sk-2 & f.-s. & g.w. & $10 \mathrm{~cm}$ & 100 & * & 0 & 0 & 0 & * & 31 & 4.1 & 65 & $\mathrm{Bt}, \mathrm{Opq}$ \\
\hline T3 & $\mathrm{Ju}$ & $y z-2$ & v.c.-s. & w. & $1.5 \mathrm{~m}$ & 99 & 1 & 0 & 2 & 57 & 31 & 7.7 & 2 & * & $\mathrm{Bt}, \mathrm{Opq}$ \\
\hline T2 & $\mathrm{Ju}$ & ar-2 & m.-s. & g.w. & $20 \mathrm{~cm}$ & 86 & 13 & 2 & 0 & 24 & 17 & 46 & 3.7 & 8.4 & Opx, Opq, Bt, Am \\
\hline T1 & $\mathrm{Ju}$ & $y z-1$ & f.-s. & g.w. & $10-15 \mathrm{~cm}$ & 97 & 3 & * & 14 & 64 & 10 & 8.4 & 3.3 & 0.1 & Opx, Am, Opq, Cpx, \\
\hline
\end{tabular}

F : formation, Ya: Yabuta F., Ju : Junicho F., w.: white, g. : gray, y. : yellow, v.c. : very coarse sand size, m.: medium sand size, f. : fine sand size, v.f. : very fine sand size, s. : silt size, G. : glass, L.M. : light mineral, H.M. : heavy mineral, *: less 1\%, Opx : orthopyroxenes, Cpx : clinopyroxenes, Am : amphiboles, Bt: biotite, Opq : opaque minerals. Data of the T2, T6 and T8 volcanic ash beds are from Ohkubo (1999).

くの層準では塊状の産状を示すが，基底から $1 \mathrm{~m}$ 付近に平行 葉理が発達する，基底から $20-30 \mathrm{~cm}$ 付近では，直径数 $\mathrm{mm}$ 大の軽石を特に多く含む．軽石の多くは繊維を束ねた形状を 示す. $1 \mathrm{~m}$ 付近の層準まで粗粒砂サイズからシルトサイズへ と級化し，それより上位はシルト質の極細粒砂サイズの火山 灰を主体とする (Fig. 4)。火山ガラスの形状は厚手の直線状 の突起を持つ扁平型（ $\mathrm{Hb}$ 型）や直線状の気泡を持つ中間型 (Cb 型) が多い（Table 1; Fig. 5). 構成粒子は $100 \%$ 近くが 火山ガラスで構成され, 石英, 長石等の軽鉱物を少量含み, 重鉣物はわずかに黒雲母と不透明鉱物を含む (Table 1)。火 山ガラスの化学組成は $\mathrm{SiO}_{2}$ の值が $77.49 \%$ 前後と比較的高 めで, $\mathrm{CaO}$ の值が $0.62 \%$ 前後と比較的低めである（Table 2 ; Fig. 6).

\section{T4 火山灰層（荒井，私信）}

この火山灰層の模式地を氷見市坂津の民家裏の露頭（Fig. 2-3）に設定する．層厚は模式地で約 $10 \mathrm{~cm}$. 灰白色，極細粒 砂サイズ〜シルトサイズのガラス質火山灰層である。 火山ガ ラスの形状は多孔質型 (Ta) 中間型 (Ca) が多い (Table 1). 重鉱物は黒雲母, 不透明鉱物を含む. 火山ガラスの化学組成 は $\mathrm{SiO}_{2}$ の值が $78.19 \%$ 前後之 $76.80 \%$ 前後の 2 つに分かれ る. また $\mathrm{K}_{2} \mathrm{O}$ の值が $1.55 \%$ 前後と低い (Table $2 ;$ Fig. 6 ).

T9 火山灰層 (Arai et al., 1991)

この火山灰層は模式地か設定されていないため, 本研究で は氷見市朝日山の国道 160 号線沿いの露頭（Fig. 2-3）に設 定する. 層厚は模式地で約 $20 \mathrm{~cm}$. 灰白色, 極細粒砂〜シル
トサイズのガラス質火山灰層である。 火山ガラスの形状は中 間型 $(\mathrm{Ca}, \mathrm{Cb})$, 突起を持つ扁平型 $(\mathrm{Hb})$ が多い (Table 1). 重鉱物は黒雲母, 角閃石をわずかに含んでいる. 火山ガラス の化学組成は $\mathrm{SiO}_{2}$ の值が $78.6 \%$ 前後之高い（Table $2 ; \mathrm{Fig}$. 6).

\section{4. 火山灰層の対比}

本研究は藪田層と十二町層において 15 枚の主要な火山灰 層の記載岩石学的特徵を比較した結果, 対比されると考えら れる 2 組の火山灰層を見いだした。 よって, 以下に示す。

\section{藪田層 MT2 火山灰層亡十二町層 T1 火山灰層}

両火山灰層の産状は層厚において MT2 が約 $90 \mathrm{~cm}, \mathrm{~T} 1$ が 約 $15 \mathrm{~cm}$ (Fig. 3) 之差が認められるものの, 細粒砂サイズか らシルトサイズのガラス質火山灰という点で共通している. 火山ガラスの形状はどちらも薄手の扁平型 (Hb) が共通して 多い（Table 1; Fig. 5). また高温型の石英を共通して含む (Fig. 5). 重鉱物はどちらあ斜方輝石, 角閃石, 単斜輝石を含 む. 化学組成は $100 \%$ 再計算時で各組成値が標準偏差の範囲 内で一致し, 特に $\mathrm{SiO}_{2}$ の值が 78.4-78.6\% と比較的高く, そ れに加えて $\mathrm{Al}_{2} \mathrm{O}_{3}$ の值が $11.8-12.1 \%$ 之比較的低い点で他の 火山灰層から区別される（Table 2; Fig. 6)。これらの特徵 から両火山灰層は対比されることが考えられる.

\section{數田層 UN 火山灰層 $匚 十$ 二町層 T3 火山灰層}

$\mathrm{UN}$ の層厚は約 $2.5 \mathrm{~m}$, T3 火山灰層の層厚は $1.3 \mathrm{~m}$ である (Fig. 4). どちらも径数 $\mathrm{mm}$ ほよ゙の軽石を含むガラス質火山 灰という点で共通している．また全体として塊状の産状を示 
Table 2. Volcanic glass chemistry in volcanic ash beds in the Nadaura-Ao area (2-a) and the Asahiyama area (2-b).

Table 2-a, Nadaura-Ao Area

\begin{tabular}{|c|c|cccccccccc|c|c|c|}
\hline Name & Sample & $\mathrm{SiO}_{2}$ & $\mathrm{TiO}_{2}$ & $\mathrm{Al}_{2} \mathrm{O}_{3}$ & $\mathrm{FeO}^{*}$ & $\mathrm{MnO}$ & $\mathrm{MgO}$ & $\mathrm{CaO}$ & $\mathrm{Na}_{2} \mathrm{O}$ & $\mathrm{K}_{2} \mathrm{O}$ & Total & Total.2 & $\mathrm{n}$ \\
\hline OT5 & oot5 & $75.86(0.33)$ & $0.39(0.08)$ & $13.26(0.16)$ & $1.44(0.06)$ & $0.12(0.08)$ & $0.01(0.02)$ & $1.13(0.06)$ & $4.21(0.38)$ & $3.59(0.20)$ & 100 & $92.76(0.81)$ & 12 \\
\hline UN & kun.2 & $77.37(0.32)$ & $0.18(0.08)$ & $12.84(0.18)$ & $1.04(0.08)$ & $0.06(0.06)$ & $0.00(0.00)$ & $0.66(0.04)$ & $3.08(0.30)$ & $4.85(0.17)$ & 100 & $93.74(0.54)$ & 13 \\
& kun.1 & $77.46(0.33)$ & $0.11(0.08)$ & $12.77(0.17)$ & $1.05(0.07)$ & $0.11(0.06)$ & $0.00(0.03)$ & $0.61(0.06)$ & $3.06(0.45)$ & $4.84(0.24)$ & 100 & $93.78(0.71)$ & 12 \\
\hline MT2 & mmt2 & $78.64(0.36)$ & $0.24(0.04)$ & $12.02(0.13)$ & $1.10(0.09)$ & $0.04(0.03)$ & $0.00(0.00)$ & $0.68(0.04)$ & $3.30(0.27)$ & $4.00(0.14)$ & 100 & $92.29(0.85)$ & 11 \\
\hline TT2 & tt12 & $73.77(0.52)$ & $0.53(0.05)$ & $13.89(0.26)$ & $2.79(0.19)$ & $0.15(0.05)$ & $0.20(0.20)$ & $2.88(0.18)$ & $4.18(0.23)$ & $1.68(0.05)$ & 100 & $94.16(0.53)$ & 12 \\
\hline T1 & ktt1 & $75.11(0.35)$ & $0.24(0.05)$ & $13.70(0.18)$ & $1.56(0.05)$ & $0.07(0.04)$ & $0.00(0.00)$ & $1.07(0.04)$ & $3.77(0.30)$ & $4.48(0.19)$ & 100 & $92.12(0.77)$ & 11 \\
\hline YT4 & syt4 & $75.13(0.23)$ & $0.13(0.04)$ & $13.87(0.10)$ & $1.59(0.09)$ & $0.08(0.04)$ & $0.00(0.00)$ & $0.67(0.05)$ & $3.59(0.25)$ & $4.91(0.18)$ & 100 & $94.17(0.63)$ & 11 \\
\hline YT3 & syt3 & $77.06(0.26)$ & $0.09(0.06)$ & $12.89(0.14)$ & $1.16(0.06)$ & $0.11(0.06)$ & $0.00(0.03)$ & $0.44(0.04)$ & $3.19(0.23)$ & $5.08(0.18)$ & 100 & $93.55(0.48)$ & 11 \\
\hline
\end{tabular}

Table 2-b, Asahiyama Area

\begin{tabular}{|c|c|ccccccccc|c|c|c|}
\hline Name & $\mathrm{Sample}$ & $\mathrm{SiO}_{2}$ & $\mathrm{TiO}_{2}$ & $\mathrm{Al}_{2} \mathrm{O}_{3}$ & $\mathrm{FeO}^{*}$ & $\mathrm{MnO}$ & $\mathrm{MgO}$ & $\mathrm{CaO}$ & $\mathrm{Na}_{2} \mathrm{O}$ & $\mathrm{K}_{2} \mathrm{O}$ & Total & Total.2 & $n$ \\
\hline $\mathrm{T} 9$ & as-2 & $78.60(0.30)$ & $0.21(0.04)$ & $12.62(0.14)$ & $1.00(0.06)$ & $0.06(0.03)$ & $0.00(0.00)$ & $0.84(0.05)$ & $2.93(0.33)$ & $3.73(0.33)$ & 100 & $91.36(0.44)$ & 10 \\
$\mathrm{~T} 8$ & ar-5 & $77.86(0.19)$ & $0.24(0.07)$ & $12.73(0.17)$ & $0.86(0.06)$ & $0.11(0.04)$ & $0.03(0.05)$ & $0.92(0.06)$ & $3.25(0.26)$ & $4.00(0.07)$ & 100 & $92.26(0.40)$ & 12 \\
$\mathrm{~T} 6$ & $\mathrm{yz}-3$ & $76.49(0.23)$ & $0.17(0.06)$ & $12.93(0.09)$ & $1.47(0.03)$ & $0.08(0.05)$ & $0.01(0.02)$ & $0.77(0.05)$ & $3.51(0.18)$ & $4.50(0.26)$ & 100 & $93.60(0.24)$ & 12 \\
\hline $\mathrm{T} 4$ & $\mathrm{sk}-2$ & $78.19(0.08)$ & $0.26(0.03)$ & $11.91(0.03)$ & $2.14(0.07)$ & $0.15(0.05)$ & $0.01(0.02)$ & $1.51(0.06)$ & $4.28(0.10)$ & $1.55(0.06)$ & 100 & $93.07(0.48)$ & 5 \\
& & $76.80(0.33)$ & $0.26(0.07)$ & $12.53(0.23)$ & $2.22(0.23)$ & $0.15(0.03)$ & $0.00(0.01)$ & $1.85(0.11)$ & $4.63(0.47)$ & $1.55(0.25)$ & 100 & $92.93(0.42)$ & 7 \\
\hline $\mathrm{T} 3$ & $\mathrm{yz}-2$ & $77.49(0.34)$ & $0.10(0.06)$ & $12.90(0.15)$ & $1.11(0.07)$ & $0.04(0.02)$ & $0.00(0.00)$ & $0.62(0.05)$ & $3.08(0.27)$ & $4.74(0.20)$ & 100 & $93.19(0.59)$ & 12 \\
$\mathrm{~T} 2$ & ar-2 & $75.83(0.44)$ & $0.23(0.08)$ & $13.66(0.16)$ & $1.56(0.09)$ & $0.08(0.05)$ & $0.00(0.00)$ & $1.00(0.08)$ & $3.19(0.31)$ & $4.44(0.11)$ & 100 & $93.11(0.50)$ & 11 \\
$\mathrm{~T} 1$ & $\mathrm{yz}-1$ & $78.47(0.25)$ & $0.24(0.06)$ & $11.88(0.14)$ & $1.09(0.05)$ & $0.09(0.05)$ & $0.01(0.02)$ & $0.68(0.06)$ & $3.40(0.34)$ & $4.08(0.27)$ & 100 & $92.44(0.51)$ & 12 \\
\hline
\end{tabular}

Each datum is recalculated to $100 \%$. $\mathrm{FeO}^{*}$ : total $\mathrm{Fe}$ as $\mathrm{FeO}$, Total 2 : not recalculated total, $\mathrm{n}:$ number of analyzed glass shard, ( ) : standard deviation in parentheses. For explanation of other marks, see Table 1. Data of the T2, T6 and T8 volcanic ash beds are from Ohkubo (1999).

し，部分的に葉理が発達する点で共通する．火山ガラスの形 状は厚手の扁平型・中間型が多く, 直線状の突起・気泡が発 達している点で共通している（Table 1；Fig. 5)。重鉱物は 両者共に黒雲母をわずかに含む. 火山ガラスの主要化学組成 は $100 \%$ 再計算時で各組成值が標準偏差の範囲内で-一致し, 特に $\mathrm{SiO}_{2}$ の值が $77.3-77.5 \%$ 前後と比較的やや高く, $\mathrm{K}_{2} \mathrm{O}$ の 值が $4.74-4.85 \%$ 前後之比較的高い点で特徽的である（Table 2 ; Fig. 6).これらの特徴から雨火山网層は対比されること が考えられる。

\section{微化石層序の検討}

藪田・十二町両層の火山灰層の内, MT2 と $\mathrm{T} 1$ および $\mathrm{UN}$ 之 T3 火山灰層がそれぞれ共通する記載的特徵を持ち, 対比 される可能性が高いことを認めた。しかし MT2 と T1 が対 比されるとすると, 藪田層の珪藻化石層序（渡辺 1990）加ら MT2 火山灰層の年代は $3 \mathrm{Ma}$ 前後 $3 \mathrm{Ma}$ 前半と推定されて いることから，十二町層最下部付近の年代も $3 \mathrm{Ma}$ 前後〜前 半之推定されることになる。これは両角・石垣（1981）の見 積もりと比べると $1 \mathrm{Ma}$ 近くも古くなる. また， T3 火山灰層 は大久保 (1999) により頭川層, 高窪層へ上追跡され, 北陸 地域の鮮新統の重要な鍵層となっている。ささら MT2 火山 灰層は富田・黑川（1999）により広域火山灰層土生滝 I-MT2 火山灰層として報告され，UN 火山灰層屯また富田・黒川 （1995）, 黒川（1999）により, 東海層群の南谷 2 火山灰層と 新潟地域の西山層の Ftj 火山灰層に対比されている。

本研究ではMT2-T1, UN-T3 火山灰層に沶ける対比の検 証之，対比された場合に広域火山灰層（土生滝 I-MT2 火山 灰層) へ微化石層序の年代デー夕を提供することの二つを目 的に，十二町層下部に扔いて珪藻化石層序と石灰質ナンノ化
石層序の検討を行った。

\section{1. 微化石試料}

水見市清水北西の沢沿い（Fig. 2-4）にて柱状図を作成し， 基底から $40 \mathrm{~m}$ 付近の層準まで 12 試料（Fig. 7) を採取して 下から JN01〜JN12 と番号を付けた。

\section{2. 珪藻化石層序}

珪藻化石の試料処理は小泉・谷村 (1978)の方法に従った。 プレパラート上の無作為に選んだ測線に沿って, 珪藻化石款 を光学顕微鏡により 100 個同定・算定し, その後約 400 個か ら500 個の珪藻殼を観察して時代決定に有効な種の有無を検 討した。

JN01，02，05，06，07，09 の計 6 試料の検討を行い，全試 料から珪藻化石が産出した（Fig. 7; Table 3). 全試料から 年代の指標として有効な Neodenticula koizumii が産出し, JN01，02，05，06の の 4 試料で Neodenticula kamtschatica が 産出したが, Neodenticula seminae はどの試料から鏟出し なかった。また JN 01，02，05，07，09の5試料から Thaiassiosira convexa が産出した (Fig. 7 ; Table 3).

本研究の珪藻化石の結果から十二町層下部の地質時代は次 のように解釉される。 JN01〜06 は N. kamtschatica と N. koizumii の共存加ら Yanagisawa and Akiba (1998) の $N$. koizumii-N. kamtschatica 带（NPD8）にあたる.一方, JN 07 と09 は. koizumii が産出し, N. kamtschatica が産出し ないことから, Yanagisawa and Akiba (1998) のN. koizumii 帯（NPD9）にあたる（Fig. 7)。なお，JN06 とJN 07 の間に引加机る両化石帯の境界（NPD8/9）の年代は Yanagisawa and Akiba（1998）によると2.7-2.6 Ma とされ ている。

\section{3. 石灰質ナンノ化石層序}



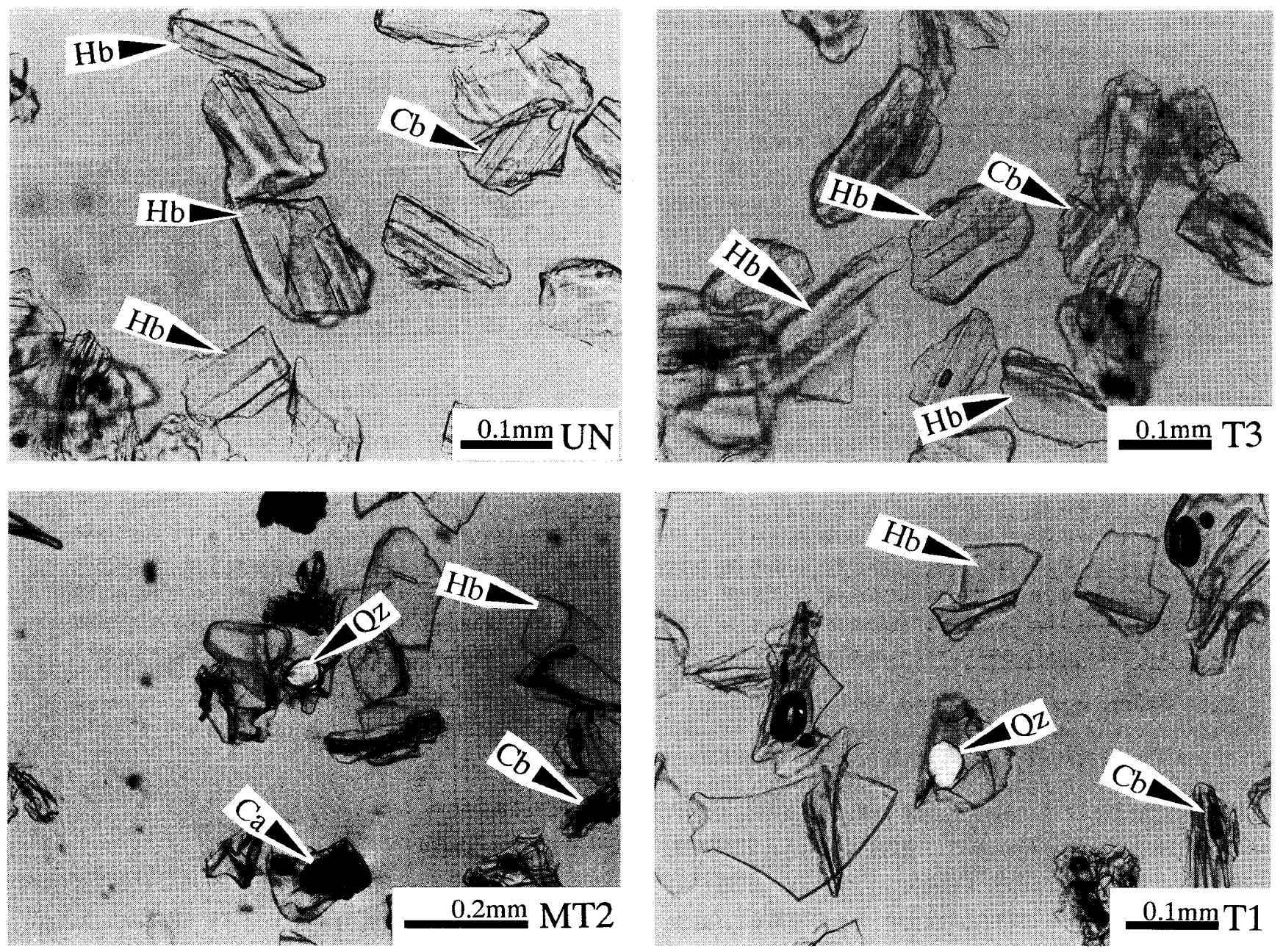

Fig. 5. Microphotographs of grain components of the T1, T3, UN and MT2 volcanic ashes in $3 \phi$ fraction. Microphotographs of the MT2 and T1 are rotated lower polar for $30^{\circ}$ from crossed position. Classification of volcanic glass shapes ( $\mathrm{Hb}, \mathrm{Ca}$ and $\mathrm{Cb}$ ) is based on Yoshikawa (1976). Qz: quartz.

試料はいずれも高山（1978）の方法で処理し，プレパラー トを作成した，プレパラート上の無作為に選んだ測線にそっ て，石灰質ナンノ化石を光学顕微鏡下により 100 個同定・算 定し，それとは別に年代の指標となる種の存否をプレパラー ト全面について確認した。

石灰質ナンノ化石の検討を JN01, JN03〜JN12 の計 11 試 料で行い（Fig. 7), 全試料からその産出を認めた. JN01〜05 までは小型の Reticulofenestra 属とDictyococcites 属を主体 とした群集であるが，JN06 から上位は Coccolithus pelagicus が主体の群集へと大きく変化している. Helicosphaera sellii は連続しないむのの全体的に産出する.小型の Gephyrocapsa 属はJN11のみで認められた。

本研究の石灰質ナンノ化石の結果から, 十二町層下部の地 質時代は次のように解釉される。 Reticulofenestra pseudoumbilicus が産出しないことから Sato et al. (1991) の年代 基準面 21 以降, また Gephyrocapsa caribbeanica も産出し ないことから年代基準面 12 以前であると考えられる。 JN06 から小型の Reticulofenestra 属の個体数が大幅に減少し, Coccolithus pelagicus の個体数が大幅に増加し, Reticulofenestra sp. Eが多産している. この変化は Sato and
Kameo（1996）の Datum A（2.75 Ma;佐藤ほか, 1999）に 相当する.

考察

\section{1. 數田層と十二町層の対比}

藪田層之十二町層の岩相層序区分 - 対比については, 徒来 より見解の相違があった。槙山（1930）は灘浦海岸沿いに分 布する石灰質シルト岩, 朝日山周辺の石灰質シルト質細粒砂 岩を藪田層と命名し, 朝日山周辺の石灰質粗粒砂岩を皮見層 と命名した。 その後, 朝日山周辺の石灰質粗粒砂岩を藪田層 にするか，藪田層の上に重なる別の地層とするかで見解が分 かれたが，朝日山周辺の石灰質シルト質細粒砂岩を藪田層に 含め, 灘浦海岸周辺の藪田層と同時代に対比している（例え ば，池辺，1949；今井ほか，1966）.

このような背景のもと, Hasegawa（1979）は浮遊性有孔 虫化石之石灭質ナンノ化石層序により朝日山周辺に分布する 主に石灰質シル卜質砂岩と石灰質粗粒砂岩からなる地層の年 代が鮮新世後期から更新世前期であることを示し, 十二町層 と命名して藪田層から独立させた。 Hasegawa（1979）は藪 田層の最上部に挟まれる火山灰層を $\mathrm{Y} 6$, 十二町層の最下部 

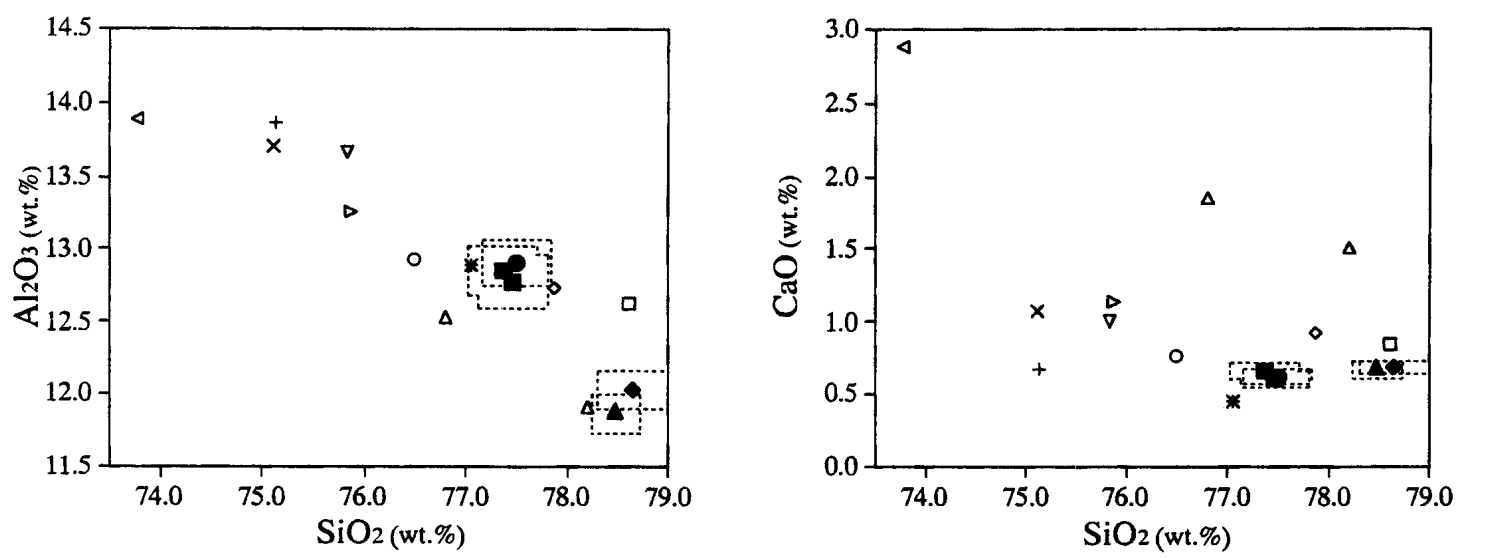

ㅁ $\quad$ T9

- T8

- T6

$\triangle \quad$ T4

- T3

$\nabla \quad$ T2

$\triangle \mathrm{T} 1$

$\triangleright \quad$ OT5

- UN

- MT2

$\triangleleft \quad$ TT2
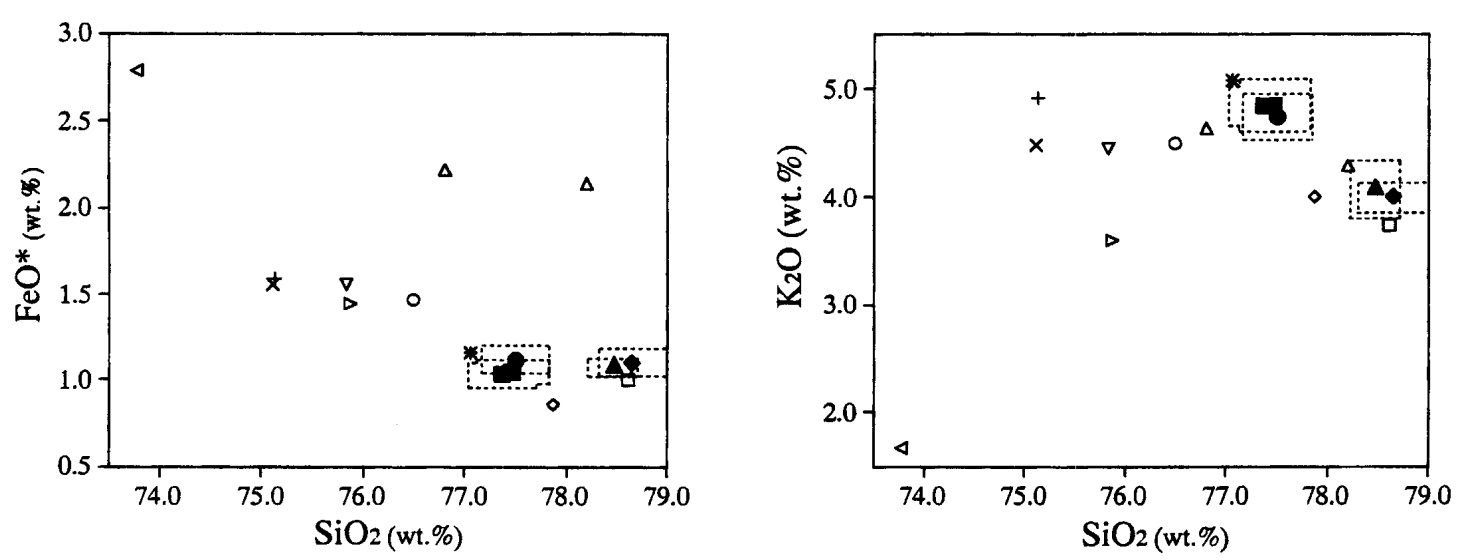

$\times \quad$ TT1

+ YT4

* YT3

Fig. 6. Chemical components of volcanic glass shards in the volcanic ash beds at the Yabuta and Junicho Formations. Areas of broken line mean areas of standard division. For raw data, see Table 2.

に挟まれる火山灰層を J1 と名づけ，産状の類似性をもとに 両火山灰層を対比した。両角・石垣（1981）は藪田層の浮遊 性有孔虫を検討し, Globorotalia inflata praeinflata が $2 \mathrm{Ma}$ 付近と $2 \mathrm{Ma}$ 後半 $3 \mathrm{Ma}$ 前半付近の二つの層準に多産する ことを認め, 十二町層最下部にも Grt. inflata praeinflata の 多産を認奴。その上で両角・石垣（1981）は十二町層最下 部之藪田層の $2 \mathrm{Ma}$ 付近の Grt. inflata praeinflata の多産層 準を対比し，Hasegawa（1979）の火山灰層による対比と調 和的な結果を示した。高山ほか（1988）は薮田層と十二町層 の石灰質ナンノ化石を検討して敨田層と十二町層下部を上部 鮮新統としたものの，両層の正確な層序関係は不明とした。

本研究で珪藻化石を検討した結果, T3 火山灰層の直下ま でN. kamtschatica が産出することから，T3 の付近に2.7$2.6 \mathrm{Ma}$ の N. koizumii-N. kamtschatica 帯とN. koizumii 帯 の境界を引くことができる（Fig. 7)。また，石灰質ナンノ化 石層序の検討から，2.75 Ma の Datum A（Sato and Kameo, 1996）が T3の $4 \mathrm{~m}$ 下位に引かれるので，十二町層での珪藻 とナンノ化石の結果はほぼ調和する。一方, 藪田層では, Cronin et al. (1994) により UN 火山灰層の直下付近まで $N$. kamtschatica が産出し, UN の直下に珪藻化石層序の $N$. koizumii-N. kamtschatica 帯とN. koizumii 帯の境界が引か れている. UN と T3 火山灰層は記載的特徵が一致し, 珪藻 化石層序上の位置でもほぼ一致しており, 対比される. 一方, $\mathrm{MT} 2$ 火山灰層之 $\mathrm{T} 1$ 火山灰層についても, $\mathrm{T} 1$ が $N$. koizumii-N. kamtschatica 帯中に位置し, MT2 屯藪田層の
$N$. koizumii-N. kamtschatica 帯の中部層準に位置する （渡辺，1990)。また，MT2 は UN の約 $25 \mathrm{~m}$ 下位に位置し， $\mathrm{T} 1$ は T3 の約 $17 \mathrm{~m}$ 下位に位置して抢り, 層位学的にも調和 的する。したがって，MT2 と T1 についてあ記載的特徵と珪 藻化石層序の点加ら対比される.

2 組の火山灰層が対比されることが明らかになったが，従 来の古地磁気層序の検討結果との間には問題が存在する.

伊藤・渡辺（1997）は藪田層中に挟まれる火山灰層の古地磁 気極性を検討した結果, MT2・UN 両火山灰層とあ正帯磁之 し, 従来の微化石層序（渡辺，1990）を利用して Gauss Chron と解釈している。 これに対して，十二町層下部の古地 磁気は山崎ほか（1983）がデー夕のばらつきの大きい中間帯 磁の測定結果を得て，微化石層序之の兼敉合い加ら Matuyama Chron と解积している. Arai et al.（1991）は $\mathrm{T} 1$ と $\mathrm{T} 3$ 火山灰層の古地磁気を測定して，T3に関して 95\% 以上の信頼角を示す $\alpha 95$ (Fisher, 1953）の值が大きいこと から疑問符を付けているあのの, 両火山灰層と屯逆帯磁とし て下部全体を Matuyama Chron 之解釉した。ささらに T1 と T 3 火山灭層の間に正帯磁を認め, 正帯磁が Reunion Subchronの可能性があるとしたこのようにMT2 と T 1 および UN とT3の対比が正しいと前提すれば, MT2 と T 1，UN 之 T3 のそ机ぞれぞちらかが，二次的な残留磁化の影 響を受けて本来の一次的な残留磁化を示していないことにな る.

$95 \%$ 以上の信頼角を示す $\alpha 95$ （Fisher，1953）の観点から, 
Table 3. Occurrence of diatom fossils in the lower part of the Junicho Formation. Numerals represent valve numbers during routine 100 counts. Asterisk "*" indicates valves encountered after the routine count.

\begin{tabular}{|l|c|c|c|c|c|c|}
\hline & JNO & JNO & JNO & JNO & JNO & JNO \\
& 1 & 2 & 5 & 6 & 7 & 9 \\
\hline Actinocyclus oculatus & & & 1 & & & \\
Actinoptychus senarius & & 2 & 1 & 1 & 1 & \\
Amphora spp. & & & 3 & $*$ & $*$ & 1 \\
Aulacoseira granulata & 1 & & & & & \\
Azpeitia vetustissima & 1 & & & & & \\
Cocconeis costata & & 1 & 4 & & & 2 \\
Cocconeis scutellum & 3 & 1 & 4 & 2 & 3 & \\
Cocconeis vitrea & & $*$ & 1 & 1 & 2 & 5 \\
Coscinodiscus marginatus & & 1 & 1 & 3 & 3 & $*$ \\
Coscinodiscus radiatus & & & & & & $*$ \\
Cosmiodiscus insignis & 2 & & & & & \\
Delphineis surirella & 1 & & & 1 & & \\
Delphineis spp. & 1 & $*$ & $*$ & & 2 & \\
Denticulopsis crassa & & & & & & $*$ \\
Denticulopsis lauta & & & & & & $*$ \\
Diploneis bombus & 2 & 1 & 1 & 2 & 1 & 1 \\
Diploneis smithii & $*$ & & 1 & 1 & 1 & 1 \\
Diploneis spp. & 2 & & & & $*$ & 1 \\
Eunotia spp. & & & $*$ & 1 & & \\
Grammatophora spp. & 1 & 4 & 1 & 2 & 1 & 3 \\
Hemidiscus cuneiformis & & & & 1 & & \\
Navicula spp. & 5 & 1 & 4 & 4 & 15 & 3 \\
Neodenticula kamtschatica & 2 & 1 & $*$ & 2 & & \\
Neodenticula koizumii & 12 & 3 & 4 & 24 & 17 & 6 \\
Nitzschia extincta & 1 & & & 1 & & \\
Paralia sulcata & 20 & 21 & 32 & 22 & 28 & 39 \\
Plagiogramma staurophorum & & $*$ & 2 & & 1 & 2 \\
Rossiella tatsunokuchiensis & & & & $*$ & 1 & \\
Stephanopyxis spp. & 4 & 4 & 3 & & & \\
Thalassionema nitzschioides & 34 & 58 & 29 & 26 & 14 & 30 \\
Thalassiosira antiqua & 5 & $*$ & 3 & 2 & 6 & \\
Thalassiosira convexa & 1 & $*$ & $*$ & & $*$ & 1 \\
Thalassiosira lineata & 1 & & & & & \\
Thalassiosira nordenskioeldii & & & & $*$ & & \\
Thalassiosira oestrupii & & 1 & & & & \\
Thalassiosira spp. & & & \\
\hline Total & & & \\
\hline Resting spore & & & \\
\hline
\end{tabular}

伊藤・渡辺（1997）の MT2 UNの測定結果がそれぞれ $2.3^{\circ} ， 2.9^{\circ}$ に対して, Arai et al. (1991) の T1 と T3 が $32.2^{\circ}$, $82.9^{\circ}$ と伊藤・渡辺（1997）の方が信頼角が小さく，信頼性が 高い.さらに N. kamtschatica の消滅層準 (2.7-2.6 Ma) は本 研究上Cronin et al. (1994) からそれぞれ T3 とUN の直下 に位置しており，MT2-T1とUN-T3 が正帯磁とすると Gauss Chron 中に位置するという解瀵が成り立ち, 調和的 である。しかし，T3 が逆帯磁であるとすると Gauss Chron と Matuyama Chron の境界が N. kamtschatica の消滅層準 之 UN-T3 火山灰層の間に存在するという解釈が成り立ち, 本研究の微化石層序の結果と矛盾するとはい觉ない，一方， MT2-T1 が逆帯磁上すると, 藪田層の珪藻化石層序（渡辺, 1990）から $3 \mathrm{Ma}$ 前後の年代が推定されていることから， Mammoth Subchron や Kaena Subchron（それぞれ3.33-
3.22 Ma，3.11-3.04 Ma ; Cande and Kent, 1995）に対比され る可能性がある。実際に MT2 は新潟地域の Arg-2 と対比さ れているが(富田・黒川，1999)，Arg-2 とほぼ同層準の Arg 火山灰層（黑川ほか, 1989 ; 岸・宮脇, 1995 の Ar II）が逆帯 磁を示し, Gauss Chron 中の Mammoth Subchron に対比 されている(岸・宮脇, 1995)。このょうに，統計的には 伊藤・渡辺（1997）の方が信頼性が高いといえるが，微化石 層序の観点加らは伊藤・渡辺 (1997) と Arai et al. (1991) の どちらが MT2-T1 と UN-T3の一次的残留磁化を反映して いるか結論できない。一方, Arai et al. (1991) は十二町層の T1 と T3間に正帯磁を認め, Reunion Subchron 屯しくは Olduvai Subchron と推定している. しかし，その正帯磁は 本研究により珪藻化石層序の N. koizumii-N. kamtschatica 帯中で石灰質ナンノ化石層序の Datum A より下位であるこ とから Gauss Chron に対比される。

逆に火山灰層の対比が正しくないとすれば，微化石層序上 とても近い位置に類似した記載岩石学的特徵を持つ火山兏層 がそれぞれ 2 枚挟まれていることとなり，これは両層の位置 関係（Fig. 1）と露頭の連続性（Fig. 3）加ら考えにくい.こ のため伊藤・渡辺（1997）の MT2 と UN Arai et al. （1991）のT1 と T3のそれぞれどちらかが，二次的な残留磁 化の影響を受けて本来の一次的な残留磁化を示していないと 考えられる。

藪田層と十二町層の層序関係は MT2-T 1 と UN-T3の 2 組の火山兏層の対比から藪田層中部・上部が十二町層下部之 同時異相関係にある（Fig. 8)。このことは珪藻化石帯 $N$. koizumii-N. kamtschatica 帯と N. koizumii 帯の境界（2.7$2.6 \mathrm{Ma}$ ) が藪田層上部（Cronin et al., 1994）と十二町層下部 に存在し，石灰質ナンノ化石の基準面 Datum A (2.75 Ma) が十二町層下部に引けることからほぼ確実といえる。十二町 層下部の年代は従来の研究（例えば，両角・石垣，1981）よ り古く, 藪田層の珪藻化石層序（渡辺，1990）上本研究の火 山灰層の対比加ら $3 \mathrm{Ma}$ 前後 $3 \mathrm{Ma}$ 前半と考えられる.

\section{2. 従来の十二町層の微化石層序との比較}

Hasegawa（1979）は十二町層の浮遊性有孔虫之石灰質ナ ンノ化石を検討し，本研究に打ける清水-矢崎ルートの基底 から約 $27 \mathrm{~m}$ の層準に Olduvai Subchron の下限付近とされ る浮遊性有孔虫 Globoquadorina asanoi の消滅 (Maiya et al., 1976), T6 火山灰層付近で石灰質ナンノ化石 Gephrocapsa caribbeanica の出現を認めた（Fig. 9). その後, 高山 ほか（1988）は十二町層の石灰質ナンノ化石之浮遊性・底生 有孔虫を本ルートにて検討し，本研究の基底から $38 \mathrm{~m}$ 付近 の層準で G. caribbeanica の出現を認め, Takayama and Sato（1987）の基準面 11 (Sato et al., 1991 以降の基準面 12） を基底から約 $25 \mathrm{~m}$ の層準に引いた（Fig. 9).

高山ほか（1988）により G. caribbeanica の出現が報告さ れた試料 JYN2 は，本研究の試料 JN 12 の直上に位置する (高山，私信)。本研究と高山ほか（1988）の結果を総合する と, FAD G. caribbeanica はJN 12 と高山ほか（1988）の JYN2 間のわずかな区間に限定され，基準面 12 (Sato et al., 1991）は高山ほか（1988）よりも約 $10 \mathrm{~m}$ 上方に修正される 


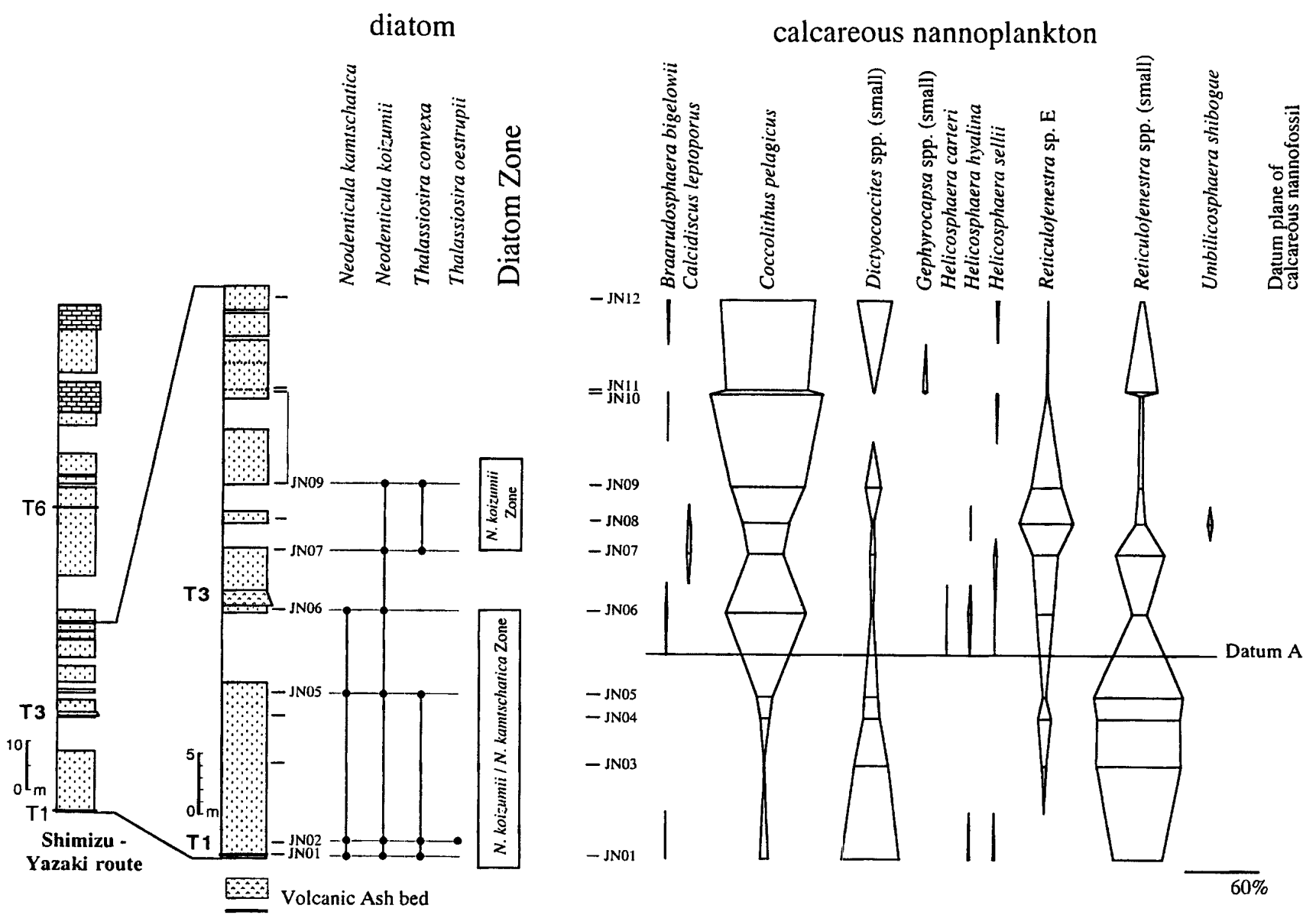

Fig. 7. Columnar sections of the Junicho Formation in the Shimizu-Yazaki route, showing sample horizons for the study of microfossils and biostratigraphic ranges of diatom and calcareous nannoplankton species. For legend of columnar sections, see Fig. 3.

(Fig. 9)。一方，珪藻化石層序により JN07-09 層準が $N$. koizumii 帯 (2.7-2.6 Maから $2.0 \mathrm{Ma}$; Yanagisawa and Akiba, 1998）に相当する。しかし，これら 2 層準に挟まれる 区間（JN09-12）については年代の考察に有効な石灰質ナン ノ化石が産出していない，また，本研究ではこの区間の珪藻 化石による生層序は検討しておらず，この区間に対する十分 な年代決定はできなかった。しかし，本研究では十二町層下 部に関する微化石年代層序の解像度を高めることができた。 すなわち，a）FAD G. caribbeanica（1.73 Ma；佐藤ほか， 1999）が JN12 とJYN2 間に位置する，b）十二町層下部が N. koizumii-N. kamtschatica 帯加ら N. koizumii 带に相当 し，両化石带の境界が JN06-07 間に位置する，c）石灰質ナ ンノ化石層序の Datum A (2.75 Ma) が JN05-06 間に位置す ることをそれぞれ認定した。

十二町層最下部の年代については, 本研究により $\mathrm{T} 1$ 火山 灰層が MT2 火山灰層と対比され, 十二町層下部の年代む 3 $\mathrm{Ma}$ 前後 $3 \mathrm{Ma}$ 前半と推定されるが，この推定は $\mathrm{T} 1$ が石灰 質ナンノ化石の Datum A （2.75 Ma）の約 $15 \mathrm{~m}$ 下位に位置 し, 問題ないといえる。 また，十二町層下部の堆積速度につ いては, 藪田層の中部から上部が $14 \mathrm{~cm} / 1000 \mathrm{yr}$ (Cronin et al., 1994）と見積もられており，藪田層上部の MT2〜UN 間 の層厚が約 $25 \mathrm{~m}$ に対して十二町層の $\mathrm{T} 1 \sim \mathrm{T} 3$ 間の層厚が約 $18 \mathrm{~m}$ であることから, T1 から T3 間の堆積速度は約 $10 \mathrm{~cm} /$
$1000 \mathrm{yr}$ と推定される。一方，T3 から高山ほか (1988) による JYN2 までの堆積速度は N. koizumii-N. kamtschatica/N. koizumii 帯の境界（2.7-2.6 Ma）とFAD G. caribbeanica (1.73 Ma ; 佐藤ほか, 1999) の層準から, 約 $3 \mathrm{~cm} / 1000 \mathrm{yr}$ 上 見積むられる。しかし，G. caribbeanica の出現は時間面にあ る程度斜交し, 北大西洋の深海コアの一部 (DSDP-IPOD Leg94, Site611）では Olduvai Subchron（1.95〜1.77 Ma ; Cande and Kent, 1995）の中部に認定されている（佐藤 · 高山, 1988). JN12～JYN2 の層準は従来の研究（山崎, 1983 ; Arai et al., 1991）により Olduvai Subchron の期間中 とされており，FAD G. caribbeanica の年代をそのまま当て はめるのには問題がある。あっとも JN 12〜JYN 2 閒が Olduvai Subchronの期間中 $(1.95 \sim 1.77 \mathrm{Ma})$ として見積 むった場合, T3 から JYN2 までの堆積速度は約 3-4 cm/ $1000 \mathrm{yr}$ よなり，見積もりは大きく違わない，いずれにして も, T3 から JYN2 までの堆積速度はきわめて遅く, 無堆積 面や削剝による不整合面が存在する可能性がある。これを明 らかにするために T3〜JYN2 間，特に JN09〜JYN2 間にお いて詳細な層序年代を検討する必要性が問題として残された といえよう。

\section{T3 火山灰層の年代と他の北陸地域に分布する鮮新-更 新統への対比}

大久保（1999）は北陸地域に分布する鮮新世後期〜更新世 


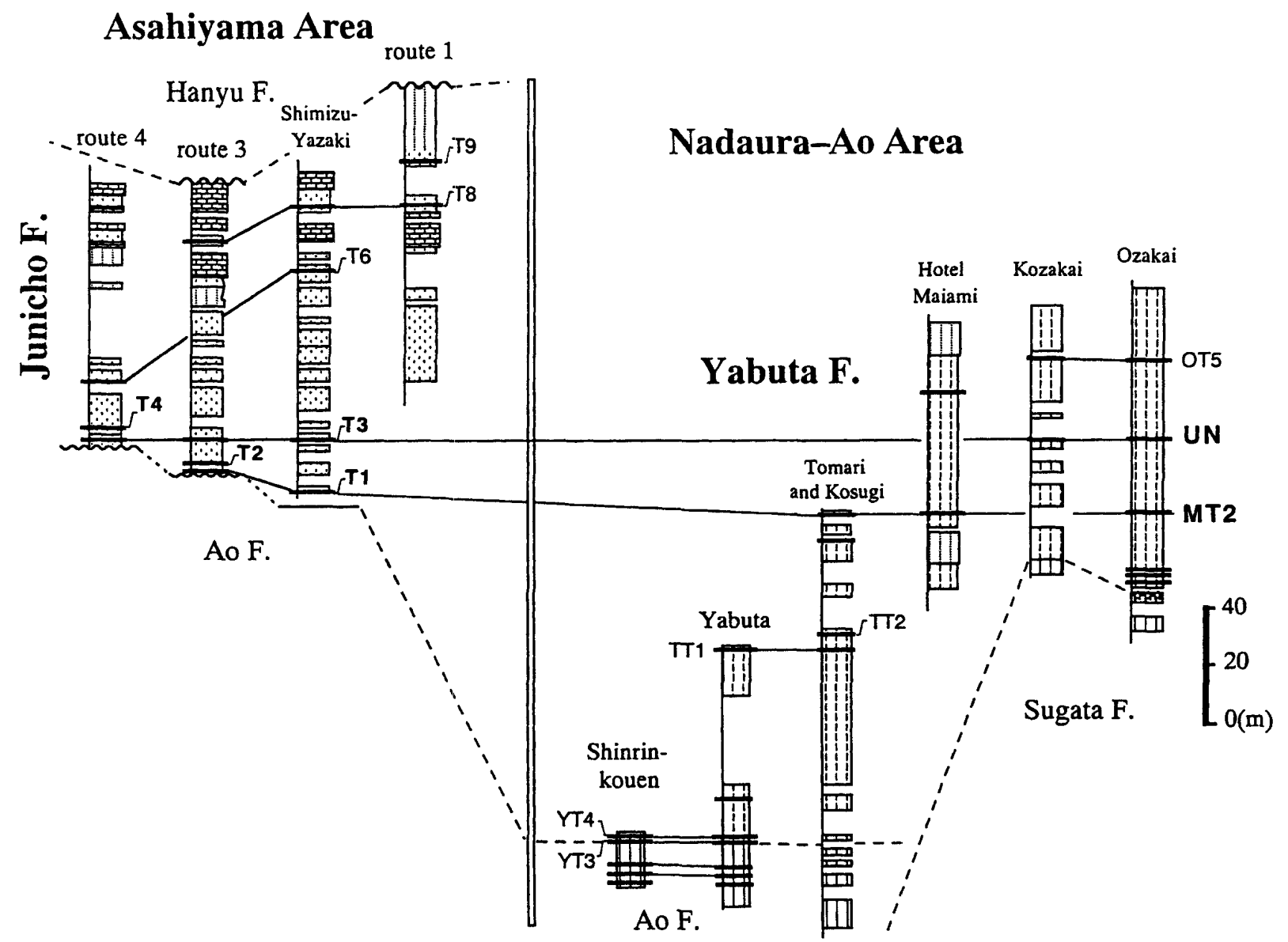

Fig. 8. Correlation between the Yabuta and Junicho Formations in the Nadaura-Ao and Asahiyama areas. For explanation of columnar sections, see Fig. 3.

前期にかけて堆積した高窪層の最上部, 頭川層, 十二町層, 大桑層に挟まれる火山灰層を四つの地域に分けて検討し, 各 地域間の対比を示した，その中で，十二町層の T3 火山灰層 が富山県高岡市北部に分布する頭川層の下部之石川県金沢市 東部少ら富山県小矢部市周辺に分布する高窪層の最上部に追 跡され，十二町層之頭川層が同時異相関係にあることを指摘 した。すすなわち, 本研究の結果は藪田層の中部・上部が十二 町層下部に対比されただけではなく, 頭川層下部や高窪層最 上部に対比されることを意味する. 大久保 (1999) は Arai et al.（1991）の十二町層の古地磁気層序をもとに T3 火山灰層 の年代を Olduvai Subchron と Reunion Subchron の間 (2.14-1.95 Ma ; Cande and Kent, 1995) と解釉し，T3 が高窪 層の最上部付近に追跡されることで高窪層の上部の年代を推 定した. しかし, Arai et al. (1991) により古地磁気層序上の Reunion Subchron とされたT1 よ T3 間の正帯磁が本研究 により Gauss Chron 之結論され, T3 の年代が珪藻化石層序 N. koizumii-N. kamtschatica 帯之N. koizumii 帯の境界付 近の年代 (2.7-2.6 Ma) であることから, 高窪層の上限の年代 は大久保（1999）の解釈より古い約 $2.6 \mathrm{Ma}$ 之推定される.

さらに數田層の UN 火山灰層は富田・黒川（1995）, 黑川 （1999）により, 東海地域の南谷 2 火山灰層と新潟地域の Ftj 火山灭層に対比されている. 今回の結果は北陸の鮮新一更新 統層序を火山灰層による対比の枠組みによって新潟・東海地
域と直接比較することが可能となったという点で意義のある ことといえる.

\section{4. 広域テフラ; 土生滝 I-MT2 火山灰の年代について}

今回, T1 と対比した MT2 は, 富田・黒川（1999）により 広域分布が報告されており, 土生滝 I-MT2 火山灰層之命名 されている，すなわち，本研究では十二町層最下部に土生滰 I-MT2 火山灰層を認めたこととなる.この火山灰の年代と

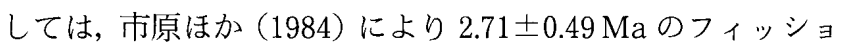
ントラック年代がえられている. 本研究の石灰質ナンノ化石 層序の結果は, 十二町層下部に打いて $2.75 \mathrm{Ma}$ を示す Datum A（Sato and Kameo, 1996）という年代基準面が土 生滝 I-MT2 火山灰層（T1）の約 $14 \mathrm{~m}$ 上位に引かれ，それよ り古い可能性が高い. 土生滝 I-MT2 火山灰層は大阪層群, 東海層群, 掛川層群, 新潟地域の西山層に追跡されている重 要な指標火山灰層であることから，よりいっそうの年代層序 学的検討 (放射年代, 古地磁気層序, 微化石層序等) が必要 之考えられる。

\section{ま と め}

1. 火山灰層 (MT2-T1, UN-T3) の対比加ら, 藪田層中 部・上部と十二町層下部を対比した。

2. 十二町層の珪藻化石層序の検討加ら大久保ほか (1999) により北陸地域に広く追跡された T 3 火山灰層が, $N$. 


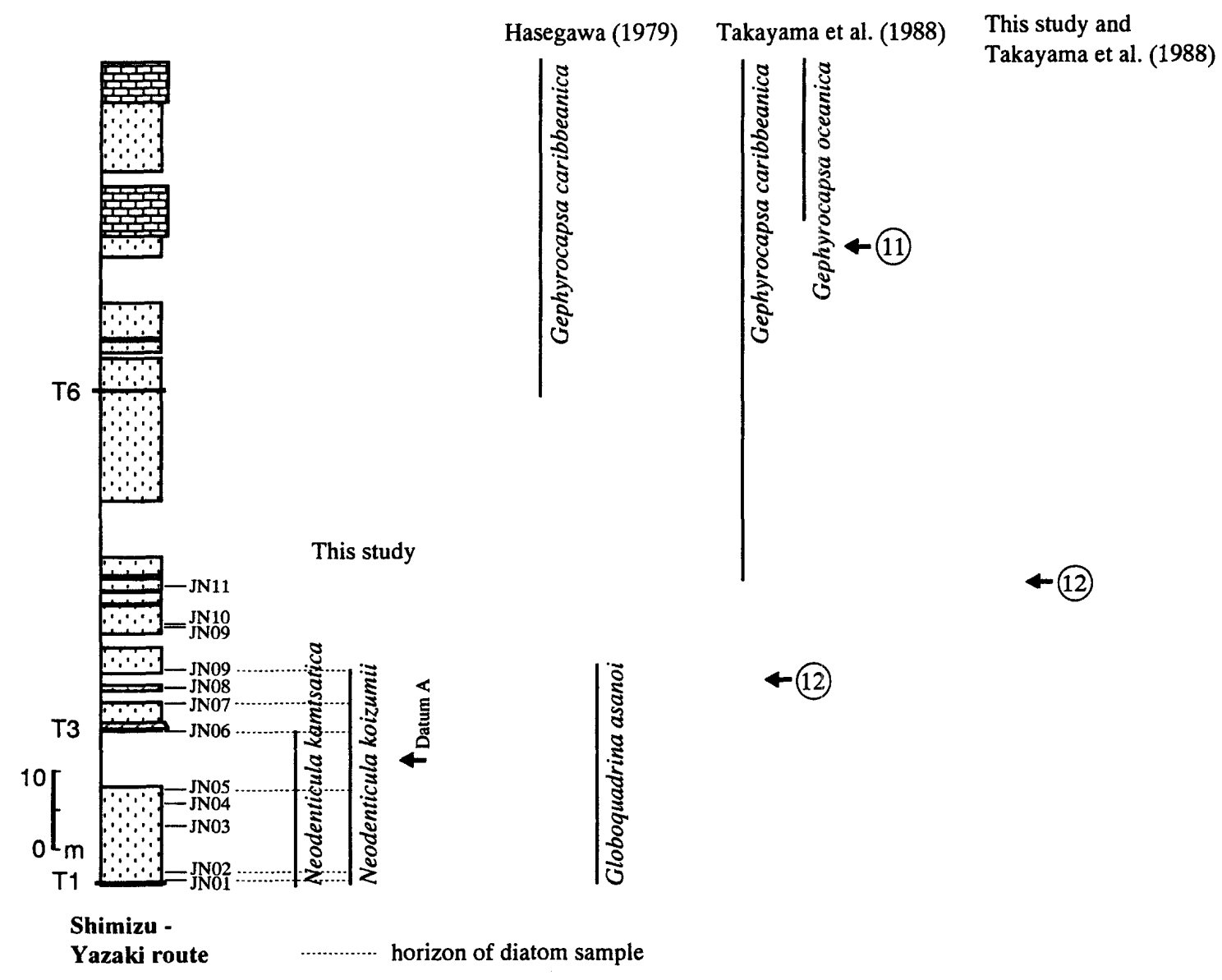

Fig. 9. Occurrences of biostratigraphic key species from the Junicho Formation indicated by this study, Hasegawa (1979) and Takayama et al. (1988). Datum A is assigned on the basis of Sato et al. (1999). (11) and (12) show calcareous nannofossil datum planes by Sato et al. (1991). For explanation of columnar section, see Fig. 3.

koizumii-N. kamtschatica 帯とN. koizumii 帯の境界 (2.7-2.6 Ma ; Yanagisawa and Akiba, 1998) の直下に位 置することを明らかにした。

3. 十二町層の T1 火山灰層が, 富田・黑川（1999）により $2.7 \mathrm{Ma}$ 付近の広域火山灰層として報告された土生滝 I-MT 2 火山灰層の相当層であることを認め, 石灰質ナンノ化石 層序の Datum A (2.75 Ma ; Sato and Kameo, 1996) の約 $14 \mathrm{~m}$ 下位に位置することを明らかにした。

$$
\text { 謝 辞 }
$$

金沢大学理学部地球学教室の神谷隆宏博士には本研究全般 にわたりお世話になり，粗稿を読んでいただいた。 十文字学 園女子大学社会情報学部の高山俊昭教授には金沢大学在職時 に十二町層の石灰質ナンノ化石について貴重なご意見をいた だいた. U.S. Geological Survey の Thomas M. Cronin 博 士には英文要旨を読んでいただいた。工業技術院地質調査所 海洋地質部の荒井晃作博士には十二町層の $\mathrm{T} 4$ 火山灰層の場 所を教えていただき，粗稿を読んでいただいた，査読者の 黒川勝己氏と匿名氏，および担当編集幹事の入月俊明氏には 適切なご指摘をいただいた，以上の方々に対し，深く感謝の 意を表します。

\section{文献}

Arai, K., Konishi, K. and Sakai, H., 1991, Sedimentary cyclicities and their implications of the Junicho Formation (late Pliocene-early Pleistocene), Central Honshu, Japan. Sci. Rep., Kanazawa Univ., 36, 49-82.

Arai, K., Sakai, H. and Konishi, K., 1997, High-resolution rockmagnetic variability in shallow marine sedement: a sensitive paleoclimatic metronome. Sediment. Geol., 110, 7-23.

荒井晃作・安井 秀 - 尾田太良, 1998, 富山県十二町層中部（後期鮮 新世）の磁性鉱物量変動と浮遊性有孔虫群集に記録された古海 洋変動. 地質雑, $104,525-537$.

Cande, S. D. and Kent, D. V., 1995, Revised calibration of polarity time scale for the Late Cretaceous and Cenozoic. Jour. Geophys. Res., 100, 6093-6095.

Cronin, T. M., Kitamura, A., Ikeya, N., Watanabe, M. and Kamiya, T., 1994, Late Pliocene climate change 3.4-2.3 Ma : paleoceanographic record from the Yabuta Formation, Sea of Japan. Palaeogeogr. Palaeoclimatol. Palaeoecol., 108, 437-455.

Fisher, R.A., 1953, Dispersion on a sphere. Proc. R. Soc., 217, 295305.

Hasegawa, S., 1979, Foraminifera of the Himi Group, Hokuriku Province, Central Japan, Sci. Rep. Tohoku Univ. 2nd ser. (Geol.). 49, 89-163.

長谷川四郎・小林博明, 1986, 能登半島南部上部新生界の地質その 1. 富山県水見市付近の岩相層序区分之層模式 (Stratotype). 北 村 信教授記念地質学論文集, 91-111.

市原 実・吉川周作・川辺孝幸・三田村宗樹, 1984, 岸和田市津田川 流域のいわゆる芝の不整合について一大阪層群の古地磁気層序 とフィッショントラック年代. 地球科学, 38, 1-16. 
池辺展生，1949，富山縣西部及石川縣東部の第三紀岿．地学，1，1426.

今井 功 - 坂本 亨 - 野沢 保, 1966, 邑知潟・虬ヶ島地域の地質. 地域地質研究報告 (5 万分の 1 地質図幅), 地質調查所, $67 \mathrm{p}$.

伊藤康人 ・ 渡辺真人, 1997, 富山県氷見地域に分布する新第三系の古 地磁気層序. 地調月報， 48，339-346.

岸清・宮脇理一郎, 1995, 新潟県柏崎平野周辺に招ける鮮新世〜 更新世の褶曲形成史. 地学雑, $105,88-112$.

小泉 格・谷村好洋, 1978 , 珪藻 - 珪質鞭毛藻. 高柳洋吉編「微化石 研究マニュアル」, 朝倉書店, 東京, 70-75.

黒川勝己, 1999, 新潟地域における七谷層〜魚沼層群の火山灰層序. 石油技協誌， 64, 80-93.

黑川勝己・丸山悦子・沢栗隆之, 1989, 新潟県中央油带北部における 椎谷層・西山層中の水底堆積テフラ. 新潟大教青紀要 (自然科学 編), 30, 39-64.

Maiya, S., Saito, T. and Sato, T., 1976, Late Cenozoic planktonic foraminiferal biostratigraphy of northwest Facific sedimentary sequences. In Takayanagi, Y. and Saito, T., eds., Progress in micropaleontology, New York, American Mus. Nat. Hist., Micropaleontology Press, 395-422.

橿山次郎, 1930, 石川富山両縣下の第三紀層概観. 地球, 14, 161-174.

両角芳郎 - 石垣武久, 1981, 藪田層の有孔虫化石群集一藪田層の時代 および下位の地層との層序関係に関連して一. 大阪市立自然史 博物館報, no. $35,1-13$.

中世古幸次郎・小泉 格・菅野耕三・米谷盛寿郎, 1972, 富山県灘浦 地方の新第三系の微化石層序. 地質雑, 78, 253-264.

大久保 弘, 1999, 鮮新-更新統, 大桑層, 頭川層, 十二町層执よび高 観層最上部の火山灰層序．地質雑，105，836-851.

Sato, T. and Kameo, K., 1996, Pliocene to Quaternary calcareous nannofossil biostratigraphy of the Arctic Ocean, with refernce to late Pliocene glaciation. In Thiede, J., et al., eds., Proc. ODP, Sci. Results, : College Station TX (Ocean Drilling Program), 151, 39-59.

佐藤時幸・亀尾浩司・三田 勲, 1999, 石灰質ナンノ化石による後期
新生代地質年代の決定精度とテフラ層序。地球科学，53，265 274 .

Sato, T., Kameo, K. and Takayama, T., 1991, Coccolith biostratigraphy of the Arabian sea. In Prell, W. L., Niitsma, N. et al., eds., Proc. ODP, Sci. Results, 117 : College Station TX (Ocean Drilling Program), 37-54.

佐藤時幸・高山俊昭，1988，石灰質ナンノプランクトンによる第四系 化石帯区分. 地質学論集, no. 30, 205-217.

高山俊昭, 1978, 石灭質ナンノプランクトン. 高柳洋吉編「微化石研 究マニュアル」, 朝倉書店, 東京, 51-59.

高山俊昭 - 加藤道雄 · 工藤哲朗 - 佐藤時幸 - 亀尾浩司, 1988, 日本海 側に発達する最上部新生界の石灰質微化石層序, その 2, 北陸堆 積盆地. 石油技協誌，53，9-27.

Takayama, T. and Sato, T., 1987, Coccolith biostratigraphy of the North Atlantic Ocean, Deep Sea Drilling Project Leg 94. In Ruddiman, W. F., Kidd, R. B., Thomas, E., et al., eds., Init. Rep. DSDP., 94, U. S. Govt. Print. Office, Washington, D. C., 651-702. 富田裕子・黒川勝己，1995，中部日本（新潟地域 - 水見層群・東海層 群）に扮ける鮮新世の広域テフラの検出. 1995 年地惑学会合同 大会演旨, 72 .

富田裕子・黒川勝己，1999，中央日本に扔ける $2.7 \mathrm{Ma}$ 頃の広域火山 灰層; 土生滝 I (大阪層群) - MT2 (水見層群) $-\mathrm{Arg}-2$ (西山層) 火 山灰層の対比. 地質雑, 105, 63-71.

渡辺真人，1990，富山県水見・灘浦地域の新第三系の層序一之くに姿 累層とその上位層との間の時間間隙について一．地質雑， 96 , 915-936.

山崎 司・藤 則雄 - 広岡公夫 • 加藤道雄 ・高山俊昭, 1983, 富山県 永見市十二町層（數田層）の古地磁気層序に関する予察的検討. 金沢大教養論集自然科学編, 20, 29-42.

Yanagisawa, Y. and Akiba, F., 1998, Refined Neogene diatom biostratigraphy for the northwest Pacific aroud Japan, with an introduction of code numbers for selected diatom biohorizons. Jour. Geol. Soc. Japan, 104, 395-414.

吉川周作, 1976, 大阪層群の火山灰層について. 地質雑, 82, 497-515.

(要 旨)

大久保 弘・佐藤時幸・渡辺真人， 2000 , 富山県北西部の鮮新-更新統， 藪田層と十二町層の火山 灰層による対比と十二町層下部の珪藻・石灰質ナンノ化石層序. 地質雑, 106, 583-596.

(Ohkubo, H., Sato, T. and Watanabe, M., 2000, Stratigraphic correlation between the Plio-Pleistocene Yabuta and Junicho Formations using volcanic ash beds, and diatom and calcareous nannofossil biostratigrahy of lower part of the Junicho Formation in northwestern Toyama Prefecture, Central Japan. Jour. Geol. Soc. Japan, 106, 583-596.)

藪田層は富山県灘浦海岸沿いに分布する鮮新世前期〜後期の地層で，十二町層は同県水見市朝 日山周辺に分布する鮮新世後期〜更新世前期の地層である。筆者らは両層に挟在する火山灰層の 記載岩石学的検討之化学分析，および十二町層下部の珪藻化石・石灰質ナンノ化石の検討し，次 の結果を得た。 (1) 藪田層と十二町層間で MT2-T1，UN-T3の 2 組の火山灰層が対比されること から，藪田層の中部・上部が十二町層の下部に対比される。(2) 珪藻化石層序の結果から北陸地 域に広く追跡されているT3 火山灰層は珪藻化石帯 N. koizumii-N. kamtschatica 帯之N. koizumii 帯の境界付近に挟在する。 またT3の $4 \mathrm{~m}$ 下位に石灰質ナンノ化石層序の Datum A （2.75 Ma）が位置する. (3)十二町層下部で認めた T1 火山灰層は広域火山灰層, 土生滝 I-MT2 火山灰層と対比され，石灰質ナンノ化石層序の Datum A より $14 \mathrm{~m}$ 下位に位置する. 